\title{
Damage Evolution of Granodiorite after Heating and Cooling Treatments
}

\author{
Mohamed Elgharib Gomah ${ }^{1,2}\left(\mathbb{0}\right.$, Guichen $\mathrm{Li}^{1, *(\mathbb{D}}$, Salah Bader $^{2}\left(\mathbb{D}\right.$, Mohamed Elkarmoty $^{3}(\mathbb{D}$ and \\ Mohamed Ismael ${ }^{3}$ (B)
}

Citation: Gomah, M.E.; Li, G.; Bader, S.; Elkarmoty, M.; Ismael, M. Damage Evolution of Granodiorite after Heating and Cooling Treatments. Minerals 2021, 11, 779. https:// doi.org/10.3390/min11070779

Academic Editor: Andreas Busch

Received: 15 June 2021

Accepted: 15 July 2021

Published: 18 July 2021

Publisher's Note: MDPI stays neutral with regard to jurisdictional claims in published maps and institutional affiliations.

Copyright: (c) 2021 by the authors. Licensee MDPI, Basel, Switzerland. This article is an open access article distributed under the terms and conditions of the Creative Commons Attribution (CC BY) license (https:// creativecommons.org/licenses/by/ $4.0 /)$.
1 Key Laboratory of Deep Coal Resource Mining, School of Mines, China University of Mining and Technology, Ministry of Education of China, Xuzhou 221116, China; mohammedel-ghareeb.12@azhar.edu.eg

2 Mining and Petroleum Engineering Department, Faculty of Engineering, Al-Azhar University, Cairo 11884, Egypt; sbadr100@azhar.edu.eg

3 Department of Mining, Petroleum, and Metallurgical Engineering, Faculty of Engineering, Cairo University, 1 Gamaa Street, Giza 12613, Egypt; mohamed.elkarmoty@cu.edu.eg (M.E.); mohamedismael@cu.edu.eg (M.I.)

* Correspondence: liguichen@cumt.edu.cn; Tel.: +86-158-0521-5566
Abstract: The awareness of the impact of high temperatures on rock properties is essential to the design of deep geotechnical applications. The purpose of this research is to assess the influence of heating and cooling treatments on the physical and mechanical properties of Egyptian granodiorite as a degrading factor. The samples were heated to various temperatures $\left(200,400,600\right.$, and $\left.800{ }^{\circ} \mathrm{C}\right)$ and then cooled at different rates, either slowly cooled in the oven and air or quickly cooled in water. The porosity, water absorption, P-wave velocity, tensile strength, failure mode, and associated microstructural alterations due to thermal effect have been studied. The study revealed that the granodiorite has a slight drop in tensile strength, up to $400{ }^{\circ} \mathrm{C}$, for slow cooling routes and that most of the physical attributes are comparable to natural rock. Despite this, granodiorite thermal deterioration is substantially higher for quick cooling than for slow cooling. Between $400: 600{ }^{\circ} \mathrm{C}$ is 'the transitional stage', where the physical and mechanical characteristics degraded exponentially for all cooling pathways. Independent of the cooling method, the granodiorite showed a ductile failure mode associated with reduced peak tensile strengths. Additionally, the microstructure altered from predominantly intergranular cracking to more trans-granular cracking at $600{ }^{\circ} \mathrm{C}$. The integrity of the granodiorite structure was compromised at $800^{\circ} \mathrm{C}$, the physical parameters deteriorated, and the rock tensile strength was negligible. In this research, the temperatures of 400,600 , and $800{ }^{\circ} \mathrm{C}$ were remarked to be typical of three divergent phases of granodiorite mechanical and physical properties evolution. Furthermore, $400{ }^{\circ} \mathrm{C}$ could be considered as the threshold limit for Egyptian granodiorite physical and mechanical properties for typical thermal underground applications.

Keywords: granodiorite; heating and cooling treatment; physical and mechanical behavior; failure modes; microstructure

\section{Introduction}

In the last few years, with the tremendous rise in population and the depletion of economic resources situated in the depths of the earth's crust, such as fossil fuels, the demand for alternative energy has become unavoidable. Hence, scientists turned toward other prospects to fulfil the countries' needs for energy, such as enhanced geothermal systems (EGS), a clean source of energy that is plentiful on our earth [1]. EGS has been described as tremendous, untapped, secure, and an environmentally sustainable energy option for conventional fossil fuels among several renewable energy options. In the 1970s, EGS started to appear at the Fenton Hill project in the USA, and after that, it continued to spread throughout the world [2]. These systems produce approximately 255 trillion watt-hours, almost 300 times the heat of the earth's fossil-based fuels [3-6]. However, their technological feasibility and financial returns also must be further investigated [7]. EGS 
is situated under high geothermal gradients in deep geological structures (depth about 2-4 km), particularly with crystalline rock forms with ultra-low permeability features and a tiny quantity of stored fluid $[8,9]$. Therefore, EGS sites are usually established in granite rocks all over the world, such as Fenton Hill, USA [10]; Fjäillbacka, Sweden [11]; Habanero, Japan [12]; and Basel, Switzerland [13]. Stimulation of the reservoir is one of the essential aspects of any low permeable reservoir over the lifetime to improve the production rates of the EGS, including many techniques of reservoir stimulation in the field, such as hydraulic, chemical, and thermal [14]. The EGS mechanism is based on the injection of cold water under high pressure via a well drilled into hot dry rocks (HDR) to open its natural fractures and receive heat $[15,16]$. The heated fluid is lifted to the surface by one or more extraction wells dug into the reservoir region to generate electricity when the appropriate hydraulic connection is created [17]. The hot rock is subjected to abrupt temperature changes during the injection of cold water through the borehole, contributing to the generation of thermal stresses and resulting in cooling rates, decreasing as the distance from the borehole increases $[18,19]$.

Not only rocks that existed in EGS are subjected to a high temperature but also rocks included at deeply buried nuclear waste, and after a mine fire, they are bound to the same conditions. The rock typically heats to 700 and $900{ }^{\circ} \mathrm{C}[20,21]$ and occasionally approaches the melting points of rocks [22-24]. By focusing on the technical problems associated with engineering applications, such as enhanced geothermal energy production and the disposal of radioactive nuclear waste deep underground, a thorough understanding of the thermophysical and thermomechanical behavior of rocks is essential when heating and cooling under liquid injection [25]; consequently, abundant investigations have been implemented to examine the effect of thermal damage on the physical and mechanical properties of different rocks. According to the earlier studies, one of the most critical problems is the degradation of crystalline rocks caused by temperature alteration, as thermal effects project new micro-cracks and mineralogical variations in the rock. Furthermore, microstructural conversion, especially the expansion of microcracks in the material, modify its mechanical properties [26]. As a result of this thermal expansion of minerals induced by high temperatures, rocks recorded a reduction in their mechanical properties under elevated temperatures or after high-temperature treatment, such as uniaxial compressive strength [18,27-30], elastic modulus [31,32], tensile strength [33,34], wave velocity [35-37], and so on. These reductions in mechanical properties of rocks, under thermal intrusion, are principally created in the form of the alteration in the mineral composition, microstructure, stress, time, and phase changes [38-41]. In contrast, physical properties, for example, porosity $[27,42-44]$ and permeability $[41,45,46]$ were increased.

At elevated temperatures, the rock fractures when the thermal stress caused by the expansion or contraction of different grains in touch with other grains reaches the tensile strength or rock shear strength [44,47]. Usually, these thermal fractures are generated from two principal mechanisms: (1) inconsistency in coefficients of thermal expansion between the different mineral granules (inducing inter-granular cracks) and (2) anisotropy of thermal expansion inside single minerals (causing intra-granular cracks) [48]. Hence, intra-granular cracking is generated by higher temperatures than intergranular cracking $[7,49,50]$. Thermal stress or numerous thermal gradients are typically the product of temperature variations [51,52], such as hot rock's rapid cooling incorporated in the various deep geological applications, "deep geological disposal of nuclear waste and the use of geothermal energy". Research into the various cooling rate impacts on the heated rock is therefore significant for deep geological systems. For this purpose, further literature has been carried out on the effects of thermal damage on the physical and mechanical properties of rocks, using several cooling techniques, "e.g., slow cooling (air or oven) or rapid cooling (water or $\mathrm{LN}_{2}$ )" [19,34,46,53-57].

Although many studies have focused on the relationship between various cooling methods and mechanical properties, such as compressive strength and elastic modulus, only a few investigations have been conducted on the temperature-dependent tensile 
strength of rocks under different cooling strategies. The effect of high temperature supported by various cooling methods on Australian granite's tensile strength was studied by [19]. The results confirmed that the tensile strength of Strathbogie granite increased insignificantly between room temperature and $200^{\circ} \mathrm{C}$ for a slowly cooled method, with a noticeable negative trend after this range. On the other hand, for Harcourt granite, the negative trend was rapidly clear from room temperature. In addition, because of the significant thermal shock, quick cooling had a far greater impact than slow cooling. Furthermore, there was a notable drop in the tensile strength results above $500{ }^{\circ} \mathrm{C}$, indicating a quartz mineral transition from a to $b$, matching [58]. As a result, the failure mode of granite at the specified temperature switched from brittle to quasi-brittle. Additionally, Ref. [34] investigated the behavior of granite tensile strength following subjection to different heating and cooling strategies. The results concluded that when samples were treated to $400{ }^{\circ} \mathrm{C}$ or lower, the cooling rate had less of an impact on their tensile strengths, in agreement with [31]. However, when the temperature range was $600{ }^{\circ} \mathrm{C}$ or above, water-cooled samples had the weakest tensile strengths, followed by air-cooled specimens and oven-cooled samples. The heating/cooling treatment influenced the failure modes as well, with central cracking with edge wedges occurring at lower temperatures [59] and fracture with a crushed band at the center occurring at higher temperatures, in line with $[59,60]$. Hence, the thermomechanical response of rocks indicates that as temperature rises, the tensile strength of the rocks diminishes [58,61]. The authors of [62] revealed that with increasing saturation degree, a common degradation in tensile strength and fracture features was observed.

Rock's tensile behavior involving various cooling treatments is doubtful. Additionally, tensile strength is a dominant factor in evaluating brittle material fracture resistance for several deep engineering applications, such as the host rock of the EGS injection well, the burning tunnels after being saved by water, and deep geological deposition for nuclear waste [63]. Thus, to ensure the reliability and efficiency of deep geo-engineering systems, the tensile strength properties of reservoir material must be tested under a series of cooling circumstances [64]. Previous research on Egyptian rocks neglected to study the effect of temperature on rocks' physical, mechanical, and microstructure properties. Therefore, this study attempts to investigate the alteration of physical and mechanical properties of Egyptian granodiorite rock following various heating and cooling treatments, such as a typical igneous rock in several geotechnical structures, as novel research to fill this gap. To that purpose, selected granodiorite specimens were heated to temperatures as high as $800{ }^{\circ} \mathrm{C}$ to evaluate the rock's suitability for a wide range of thermal applications, including thermal piercer cutting and deep engineering applications, as reported previously. After being subjected to two separate cooling mechanisms (slow cooling; "oven-cooling, aircooling" and rapid cooling; "water-cooling"), the physical properties (weight, density, and porosity) and P-wave velocity were then examined. Following that, the effect of thermal damage on mechanical properties and failure modes on the treated granodiorite was investigated through a series of Brazilian tests. Finally, using X-ray diffraction (XRD) and scanning electron microscopy (SEM), temperature-induced mineralogical changes and microstructure degradation were researched.

\section{Materials and Methods}

\subsection{Granodiorite Description}

Granodiorite is an intrusive igneous rock having a phaneritic structure like granite but containing more plagioclase feldspar than orthoclase feldspar. Egyptian granite is categorized into two classes: older granite, which is grey in color and varies in composition from tonalite to granodiorite, and younger granite, which is pink to red in appearance and ranges in form from granitic to alkali granite. Granitoid rocks are a prominent component of Egypt's Nubian Shield. High relief from various Pan African igneous and metamorphic rocks characterizes this region [65]. The granodiorite blocks were collected from the Abo Marw region located $130 \mathrm{~km}$ East of Aswan City, Egypt, which is outlined by longitudes $33^{\circ} 17^{\prime}$ to $33^{\circ} 28^{\prime} \mathrm{E}$ and latitudes $23^{\circ} 00^{\prime}$ to $23^{\circ} 10^{\prime} \mathrm{N}$. 
Cylindrical granodiorite samples were prepared from cut blocks (Figure 1a), with a diameter of $55.5 \mathrm{~mm}$. Forty-eight samples trimmed for Brazilian testing with a height of $30 \mathrm{~mm}$, as shown in Figure 1b, were divided into four groups, according to the American Standard Test Method (ASTM D 3967-95a). Furthermore, for P-wave velocity measurements and the uniaxial compression test, 21 specimens were cored to a diameter of $55.5 \mathrm{~mm}$ and approximately $130 \mathrm{~mm}$ in length, resulting in a sample (length to diameter) ratio of more than 2, following the ASTM D7012-14 [66]. The studied granodiorite is grey in color (salt and pepper) and predominantly composed of visible quartz, plagioclase feldspar, potassium feldspar, biotite, etc. The physical and mechanical characteristics at natural conditions are summarized in Table 1.

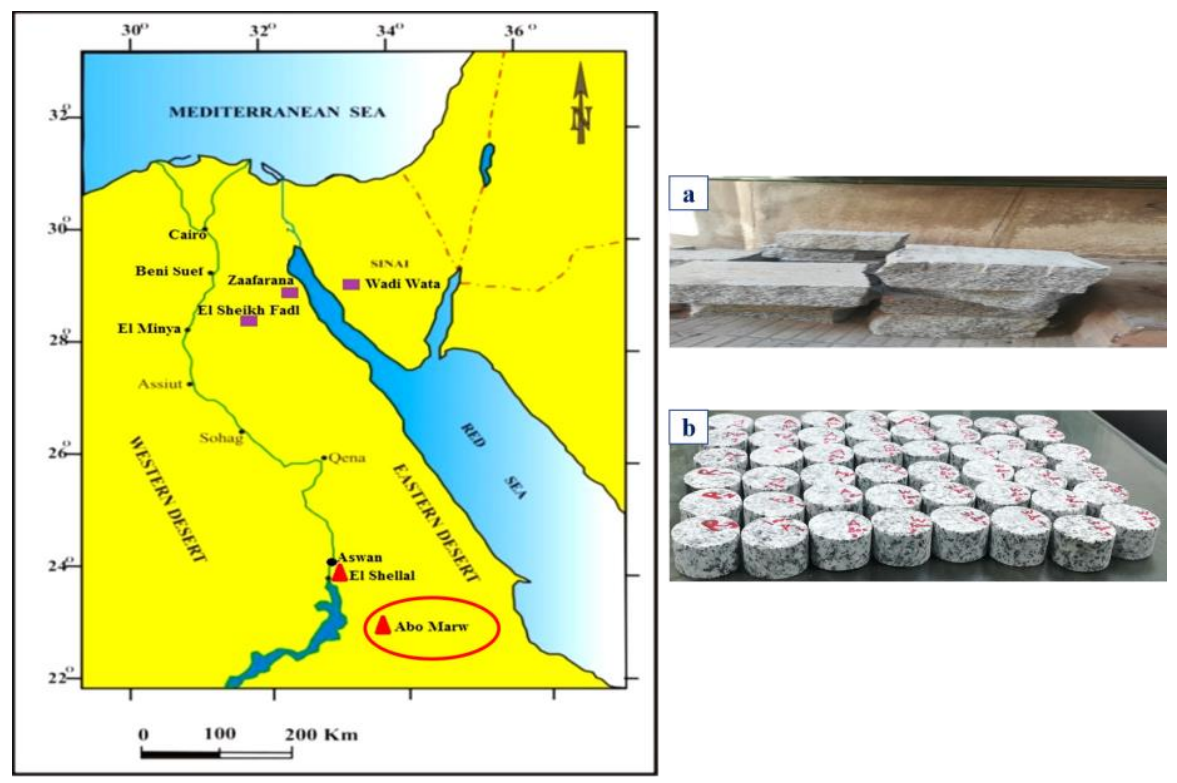

Figure 1. Location of the studied granodiorite; the collected cut blocks (a) and prepared samples (b).

Table 1. Mineralogy, physical, and mechanical properties of the studied granodiorite at room temperature.

\begin{tabular}{cc} 
Dry Density $\left(\mathrm{Kg} / \mathrm{m}^{3}\right)$ & 2610 \\
Wet Density $\left(\mathrm{Kg} / \mathrm{m}^{3}\right)$ & 2620 \\
Porosity $(\%)$ & 0.54 \\
P-waves velocity, Vp (m/s) & 5124 \\
Uniaxial compressive strength UCS (MPa) & 67.8 \\
Young's modulus, E (GPa) & 35.5 \\
Poisson's ratio, $v$ & 0.19 \\
Tensile Strength (MPa) & 10.11 \\
Color & Gray \\
Dominant minerals & Quartz (30.7\%), P-Feldspar $(38.6 \%)$, K-Feldspar \\
& $(28.1 \%)$, Biotite $(2 \%)$ \\
\hline
\end{tabular}

\subsection{Thermic and Cooling Treatment}

The granodiorite samples were heated to the target temperature in a high-temperature furnace (Nabertherm electric furnace-B410, Figure 2a). Heating changes the microstructure of rock, influencing its morphological, physical, and mineralogical features [67]. Therefore, a gradual heating rate of $5{ }^{\circ} \mathrm{C} / \mathrm{min}$ was used to avoid any potential thermal shock inside the specimens [68]. The thermic process on granodiorite was examined at four various spot temperatures: 200, 400,600, and $800^{\circ} \mathrm{C}$. After reaching the desired temperature, the specimens were preserved for $2 \mathrm{~h}$ inside the oven to assure temperature uniformity through the samples. Following that, two cooling strategies were used: (1) slow cooling 
"oven and air" and (2) rapid cooling "water quenching". Oven cooling (O-C) entailed retaining the heated samples inside the oven after turning it off with the door and vents closed. As a result, the specimens were slowly cooled. Air cooling (A-C) entailed cooling heated samples to room temperature by removing them from the oven and releasing them into the open air, which allowed the specimens to cool more quickly than OC. Quenching the heated samples in a large water tank (W-C), which simulates rapid cooling in some geothermal applications, was the fastest cooling technique.



Figure 2. The principal used instruments in this study: (a) Nabertherm electric furnace for heat treatments, (b) the SEM apparatus, and (c) the Brazilian test form.

\subsection{Physical Properties Determination}

To determine the variation in physical characteristics of granodiorite owing to cooling techniques after thermal treatment, the porosity, density, mass losses, and water absorption were investigated. Rock porosity has a key role in rocks' fluid transport and storage abilities, and an important characteristic for determining the water-absorption capability in hydrogeology [69]. It is closely related to the number and size of microcracks found in a material. The expanding of mineral particles causes the rock's porosity to rise with temperature [70]. Similarly, rock density is highly influenced by temperature and composition [71]. In this research, the physical properties of tested specimens were estimated before and after the thermal treatment, following "ISRM Suggested methods" [72]. All samples were divided into four groups of 12 samples each. Any test was performed at least three times before the average value was acceptable.

\subsection{Ultrasonic P-Wave Velocity}

Wave velocity is affected by the presence of microcracks within a rock sample. Therefore, thermally induced microcrack damage can be assessed by comparing the P-wave wave velocity before and after the thermal treatments $[73,74]$. P-wave velocity measurements were performed on UCS samples along the specimen's long axis, using an ultrasonic pulse generation and acquisition system (Pundit PL-2 device., with two 54-kHz point-source transmitter-receiver). Vaseline was used to maintain the transducers/specimen contact to ensure energy is transferred efficiently. Three groups of six specimens each were formed. The measurements were repeated five times for each sample, and the average value of the $\mathrm{P}$-wave velocity was used as the P-wave velocity value.

\subsection{XRD and SEM Analysis}

The rock physical and mechanical properties are strongly motivated by composition and internal structure. Therefore, the granodiorite mineral composition and microstructural morphology were investigated, following various thermal/cooling treatments. The 
XRD analysis was conducted on powder samples, using Bruker D8 Advance X-ray Diffractometer, from a start position $(2 \theta)$ of $5^{\circ}$ to the end position $(2 \theta)$ of $89.925^{\circ}$ with a step size of $0.061^{\circ}$. The diffraction data revealed a sample composition of quartz $(30.7 \%)$, plagioclase (38.6\%), and K-feldspar (28.1\%) as the granodiorite composition. The SEM analysis used the FEI Quanta INSPECT-S device (Figure $2 b$ ) to visualize the granodiorite microstructure after thermal/cooling processes. The observations were determined under various magnifications from $400 \times$ to $6000 \times$.

\subsection{Brazilian Tensile Test}

The Brazilian test is an indirect method for brittle material's tensile strength determination. Granodiorite tensile strength assessed through a series of Brazilian experiment tests carried on disk-shaped rock samples. The test was conducted using the compression frame (200T-CONTROLS) at the rock engineering laboratory, Faculty of Engineering, Cairo University (Egypt). The machine loading rate adjusted to $0.05 \mathrm{~mm}$ per minute (Figure 2c). During axial compression, the load vs. deformation was calculated using the software ADVANTEST9, which allowed a stress-displacement relation to be acquired. The load gradually increased at a steady rate until the sample failed in a matter of minutes. Successful tests will split the sample into two sections at the time of failure [75]. The indirect tensile strength is as estimated as follows, assuming failure occurs at the point of maximum tensile stress (i.e., at disk's center):

$$
\sigma_{\mathrm{t}}=2 \mathrm{~F}_{\max } / \mathrm{IDC}
$$

where $\mathrm{F}_{\max }$ is the max load at failure, and D, C are the sample diameter and thickness, respectively.

\section{Results}

\subsection{Impact of Cooling Method on Cooling Rate}

The effect of the cooling technology on thermal loss during the cooling process of rocks is a pivotal point. Therefore, three cooling paths for the heated granodiorite samples were examined: oven, air, and quenching in water. The cooling rate and time of the three cooling routes were measured with a stopwatch and a contact thermometer. The results revealed that the cooling rate for oven-cooled samples was linear, based on the oven's natural heat loss characteristics, while the cooling rate for samples that cooled in the air was rapid at the beginning owing to the high thermal loss, as shown in Figure 3, and then diminished nonlinearly until the sample reached room temperature, in agreement with [76]. On the other hand, the water-treated samples showed a very rapid cooling rate because of the exposure to the tremendous thermal shock from water. Table 2 summarizes the average cooling time and cooling rate. According to the results, the cooling rate of oven-cooled samples is approximately the same for all temperature groups, whereas the cooling rate of air and water-cooled approaches is continuously increasing. The intriguing fact is that air-cooled and water-cooled samples at $600{ }^{\circ} \mathrm{C}$ demand longer than those cooled in air and water at $800^{\circ} \mathrm{C}$, owing to surface macro cracks that form on and within granodiorite samples at $800^{\circ} \mathrm{C}$.

Table 2. Cooling times and rate estimates for the three cooling approaches.

\begin{tabular}{|c|c|c|c|c|c|c|}
\hline \multirow[b]{2}{*}{ Temperature $\left({ }^{\circ} \mathrm{C}\right)$} & \multicolumn{2}{|c|}{ Oven Cooling } & \multicolumn{2}{|c|}{ Air Cooling } & \multicolumn{2}{|c|}{ Water Quenching } \\
\hline & Rate $\left({ }^{\circ} \mathrm{C} / \mathrm{min}\right)$ & Time (min) & Rate $\left({ }^{\circ} \mathrm{C} / \mathrm{min}\right)$ & Time (min) & Rate $\left({ }^{\circ} \mathrm{C} / \mathrm{min}\right)$ & Time (min) \\
\hline 200 & 0.43 & 403 & 2.9 & 60 & 61.8 & 2.83 \\
\hline 400 & 0.44 & 850 & 4.3 & 88 & 78.1 & 4.80 \\
\hline 600 & 0.44 & 1300 & 5.3 & 108 & 100 & 5.75 \\
\hline 800 & 0.45 & 1710 & 8 & 97 & 225 & 3.44 \\
\hline
\end{tabular}




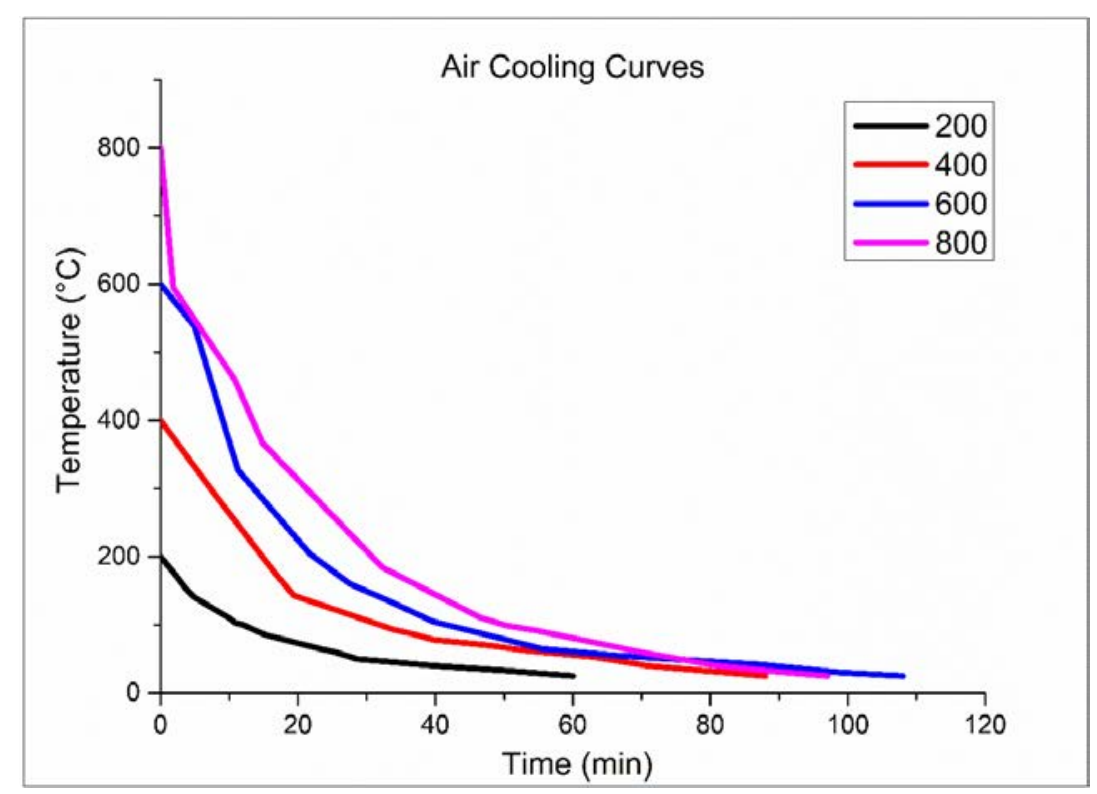

Figure 3. Air cooling curves at the different target temperatures.

\subsection{Temperature-Related Changes in the Physical Properties \\ 3.2.1. Porosity and Absorption Variations}

The thermal treatment, as previously stated, has a substantial impact on rock porosity and, as a result, granodiorite absorption of water. In a general manner, the porosity of the granodiorite samples increased continuously with rising temperature but at different rates. As depicted in Figure 4, there are three episodes of porosity and absorption change with temperature: Phase $1,25: 400{ }^{\circ} \mathrm{C}$; Phase $2,400: 600{ }^{\circ} \mathrm{C}$, and Phase $3>600^{\circ} \mathrm{C}$. Regarding Phase 1 , all cooling methods had small changes in porosity and absorption, with water-cooled samples having the highest values of $1.7 \%$ porosity and $0.7 \%$ absorption. This meant that the different types of water, i.e., absorbed, interlayer, and mineral water, escaped from granodiorite were very few during this stage. The physical characteristics of various granodiorite minerals changed in Phase 2, leading to substantial changes in porosity and absorption, and air-cooled samples had the highest porosity $(4.7 \%)$ and absorption $(1.8 \%)$ values. In Phase 3, the water-cooling method reported the highest increase in porosity and absorption, reaching $16 \%$ and $>6 \%$, respectively.
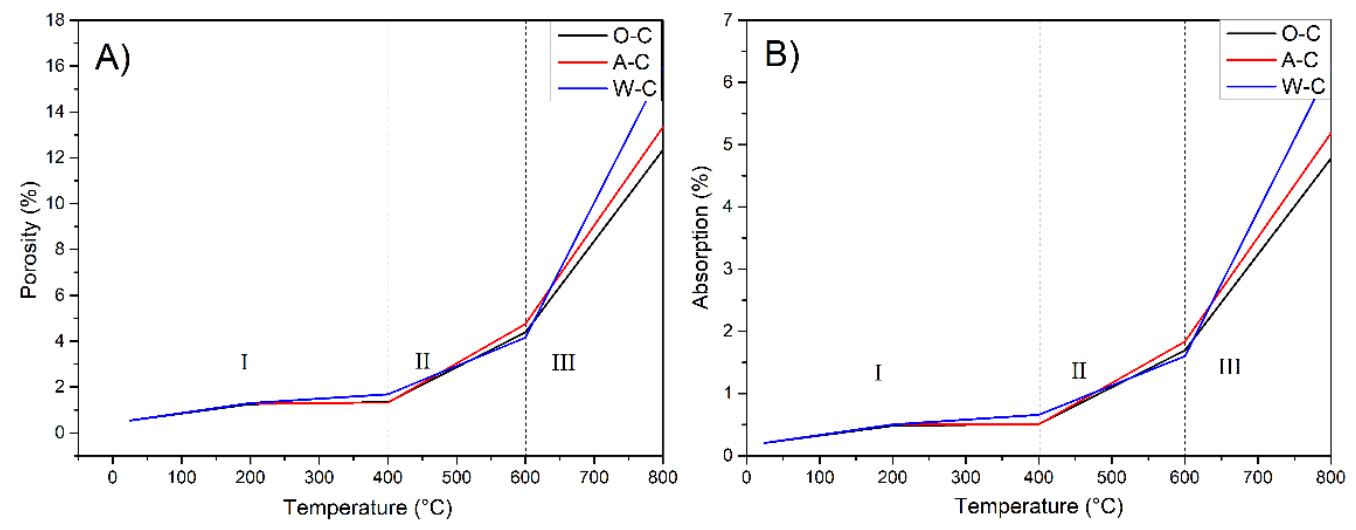

Figure 4. Temperature versus porosity (A) and absorption (B); for oven cooling (O-C), air cooling $(\mathrm{A}-\mathrm{C})$, and water cooling $(\mathrm{W}-\mathrm{C})$. Phase I $\left(25-400{ }^{\circ} \mathrm{C}\right)$, Phase II $\left(400-600{ }^{\circ} \mathrm{C}\right)$, and Phase III $(600-800$ $\left.{ }^{\circ} \mathrm{C}\right)$. 


\subsubsection{Variation in Density}

The linked mass and volume changes have the greatest impact on rock density. In general, compared to room temperature, granodiorite density has decreased gradually after heat treatment, as shown in Figure 5. Due to lesser mass loss and a minor increase in volume, the density consistently decreases up to $400{ }^{\circ} \mathrm{C}$ at a slow rate for all cooling methods. During this stage, the density values for the various cooling paths were closely connected and reported $2.58 \%$ for oven and air-cooled samples and $2.57 \%$ for water-cooled samples, at $400{ }^{\circ} \mathrm{C}$. Between 400 and $600{ }^{\circ} \mathrm{C}$, the rate of density loss became obvious, and the density readings began to drift apart. At $600{ }^{\circ} \mathrm{C}, 2.46 \%, 2.43 \%$, and $2.41 \%$ for ovencooled, air-cooled, and water-cooled samples, respectively, were recorded. Over $600{ }^{\circ} \mathrm{C}$, because of the disparity in thermal expansion between minerals, hit the limit, there was a significant decrease in density reduction ratio up to $20 \%$ for water-cooled samples. Hence, the temperature threshold for density falls was determined at $400{ }^{\circ} \mathrm{C}$.

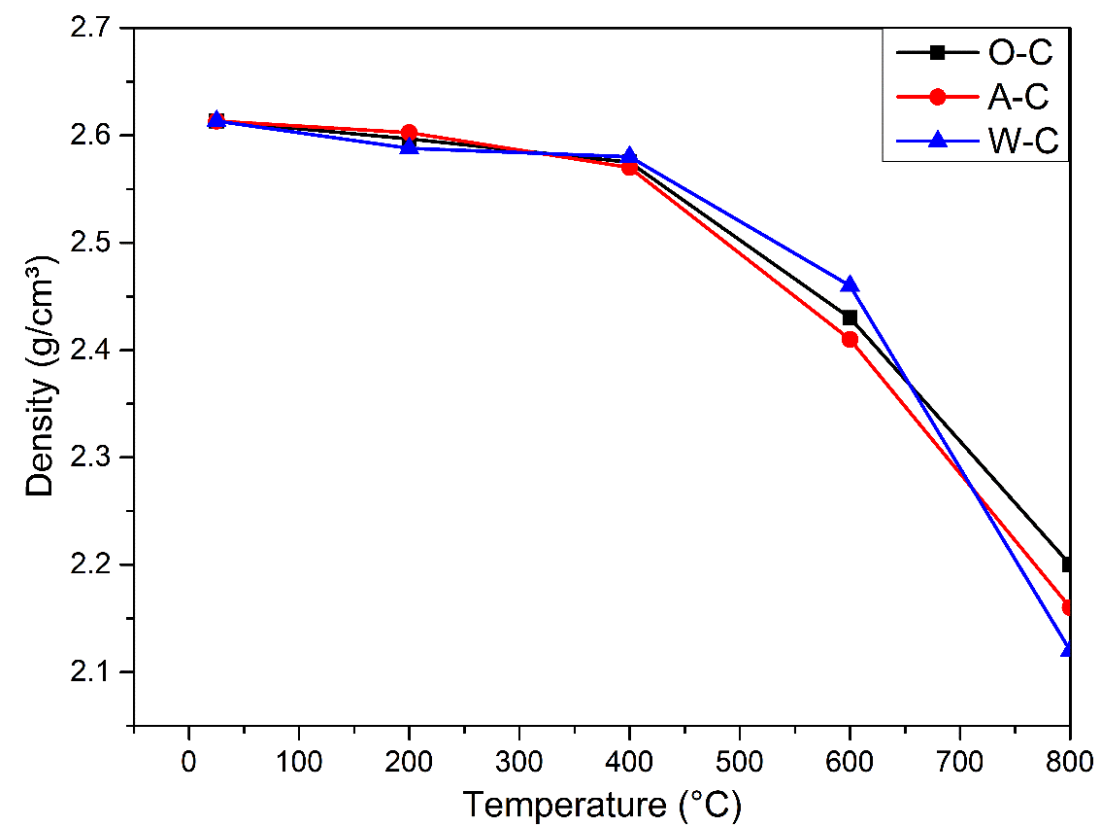

Figure 5. Density versus temperature, for the studied cooling ways.

\subsection{Temperature Effect on Ultrasonic Pulse Velocity (UPV) Measurements}

Generally, the thermal treatment had a substantial impact on the ultrasonic wave velocities of granodiorite, and this behavior was observed for the examined cooling techniques, as shown in Figure 6. It may be concluded that when the temperature rises, the P-wave velocity of rocks falls simultaneously [77]. Up to $400{ }^{\circ} \mathrm{C}$, the UPV is dropped at a moderate linear rate, and then the rate increases dramatically. For instance, the watercooled samples at $400{ }^{\circ} \mathrm{C}$ had the lowest Vp value of $2946 \mathrm{~m} / \mathrm{s}$ and the highest reduction ratio (41\%), while the oven-cooled samples had 3483 and $30 \%$ for $V p$ value and reduction ratio. The fundamental reason for that is the rapid cooling rate of water, which pronounced a large decline in Vp due to thermal shock [34]. As shown in Figure 7, the threshold of longitudinal wave velocity change started after the $400{ }^{\circ} \mathrm{C}$ limits, and the compressional wave velocity distinctly decreased for all cooling paths. At $600^{\circ} \mathrm{C}$, the longitudinal wave velocity hit its peak loss record of $962.2,850$, and $977 \mathrm{~m} / \mathrm{s}$ for oven-cooled, air-cooled, and water-cooled samples, respectively. Note that the longitudinal wave velocity was infeasible to measure at $800^{\circ} \mathrm{C}$ due to the severity of thermal cracks (assumed $0 \mathrm{~m} / \mathrm{s}$ ). Therefore, the physical and chemical changes after $600{ }^{\circ} \mathrm{C}$, which responsible for the deterioration of the longitudinal wave velocity of granodiorite. 




Figure 6. P-wave velocity variations due to heating/cooling treatments.

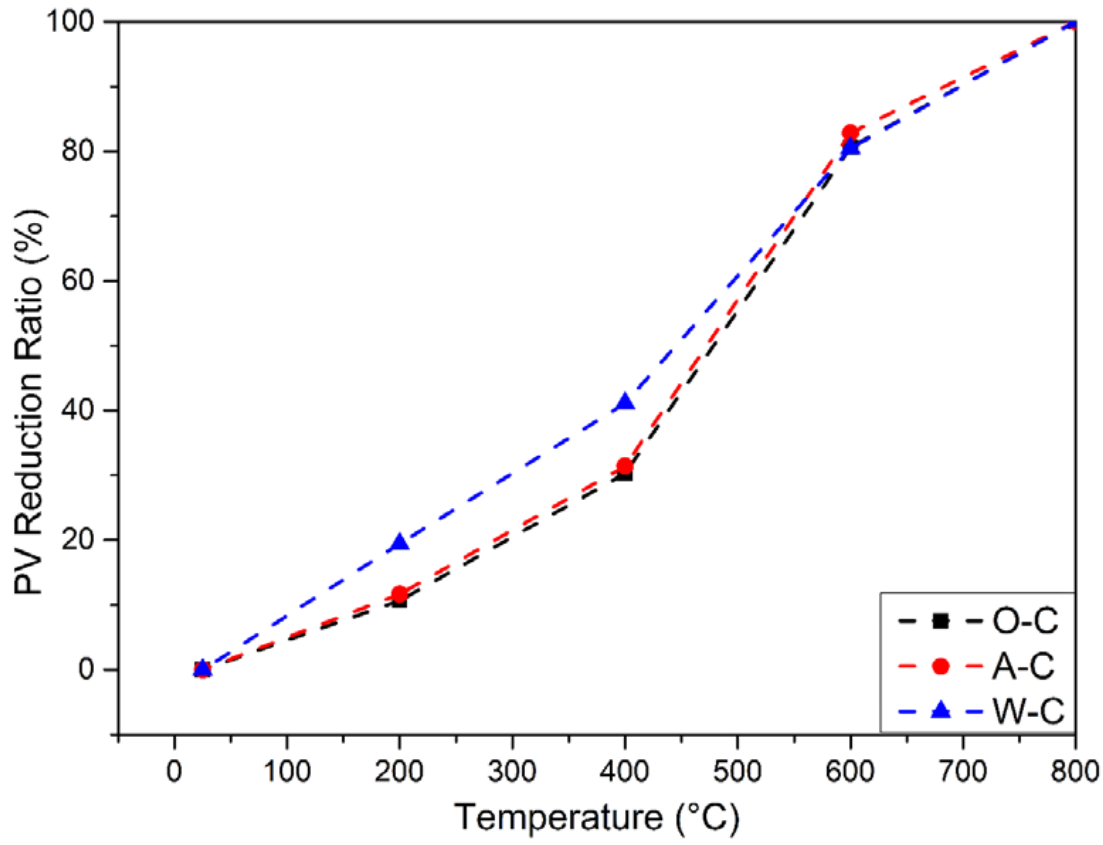

Figure 7. P-wave velocity reduction rate for all cooling paths.

\subsection{Microstructural Analysis}

Figure 8 supports the presence of three stages of mineralogical changes for ovencooled granodiorite samples. In Phase I $\left(25: 400{ }^{\circ} \mathrm{C}\right)$, the X-ray Diffraction Pattern showed minor peak variations, possibly attributable to the granodiorite's normal heterogeneity [50], while in Phase II $\left(400: 600^{\circ} \mathrm{C}\right)$, the XRD patterns changed considerably, showing increased quartz peak intensity and reduction in feldspar peaks associated with quartz phase transformations from $\alpha$ to $\beta$ phase at about $573{ }^{\circ} \mathrm{C}$. On the other hand, in Phase III $\left(600: 800{ }^{\circ} \mathrm{C}\right)$, the changes are noticeable as mineral particle decomposition plays a significant role in this phase. 


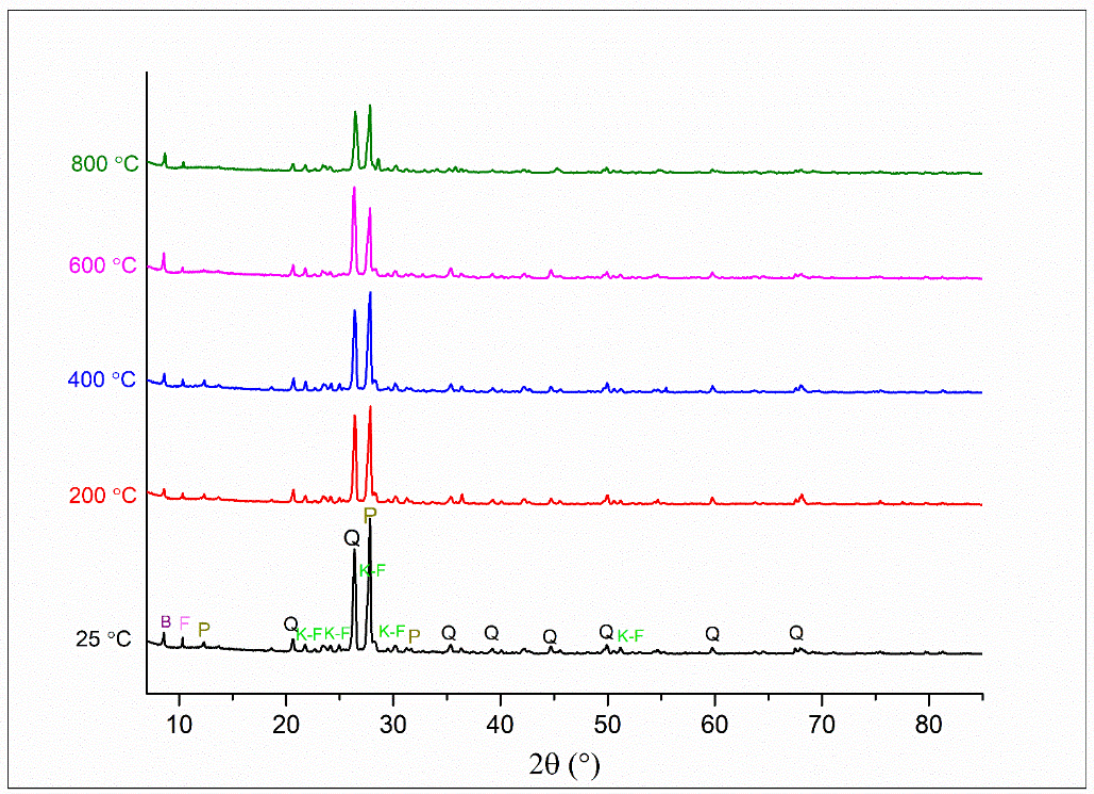

Figure 8. XRD patterns of the granodiorite samples after exposure to different heating treatments.

Thin sections of granodiorite rock were prepared and examined using scanning electron microscopy to elucidate the microcrack effect on granodiorite samples after the different heating/cooling techniques. The anisotropy between the thermal expansion/contraction coefficients of different mineral kinds, as well as the disorienting of grains throughout heating and cooling, causes microcracking in granodiorite specimens [48]. SEM investigation was used to trace granodiorite microstructure deterioration by thermal treatment. The reference sample at $25^{\circ} \mathrm{C}$ showed mineral grains closely connected, and no cracks are observed (Figure 9).

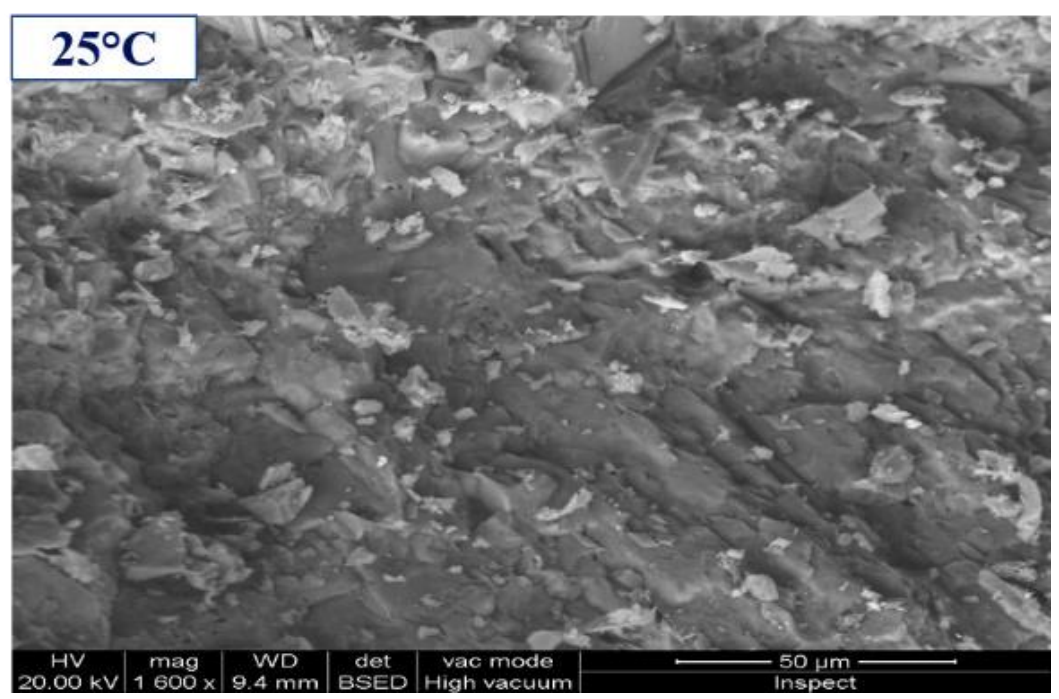

Figure 9. SEM pictures for the granodiorite original state (at room temperature).

The integrity of samples heated up to $200{ }^{\circ} \mathrm{C}$ still holds for oven-cooled and air-cooled samples (Figure 10a,b), but some cracks started to appear in the water-cooled sample (Figure 10c). As a result, there were no significant thermally induced microcracks at $200^{\circ} \mathrm{C}$, except for the water-cooled specimen. As the temperature reached $400{ }^{\circ} \mathrm{C}$, various thermal expansion created notable thermal stresses within the granodiorite structure, and intergranular cracks appeared in the oven-cooled and air-cooled samples (Figure 10d,e). In ad- 
dition, the granular borders of the mineral's grains became smoother, and the water-cooled samples had both inter-granular and trans-granular cracks (Figure 10f). The granodiorite samples' microstructure was damaged when the temperature approached $600{ }^{\circ} \mathrm{C}$, and there were enlarged microcracks within samples regardless of the cooling method (Figure $10 \mathrm{~g}-\mathrm{i}$ ). Regardless of the cooling technique, sample integrity had been compromised for the $800{ }^{\circ} \mathrm{C}$ specimens, and numerous thermal microcracks had been stimulated to link and coalescence, resulting in significantly higher macroscopic crack density and fissure widths than at $600{ }^{\circ} \mathrm{C}$ (Figure $\left.10 \mathrm{j}-1\right)$.


(A)
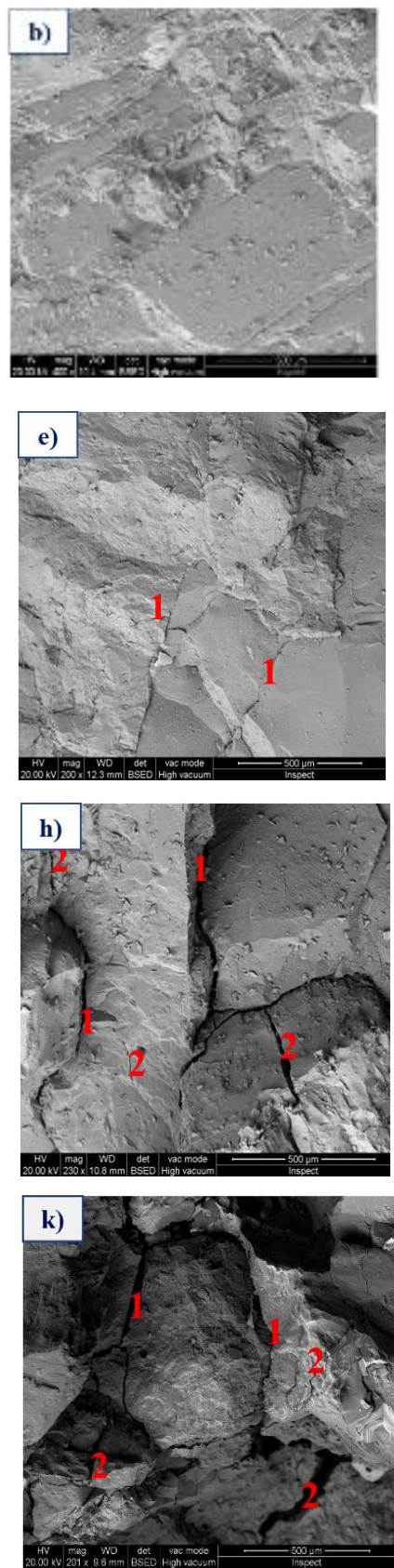

(B)
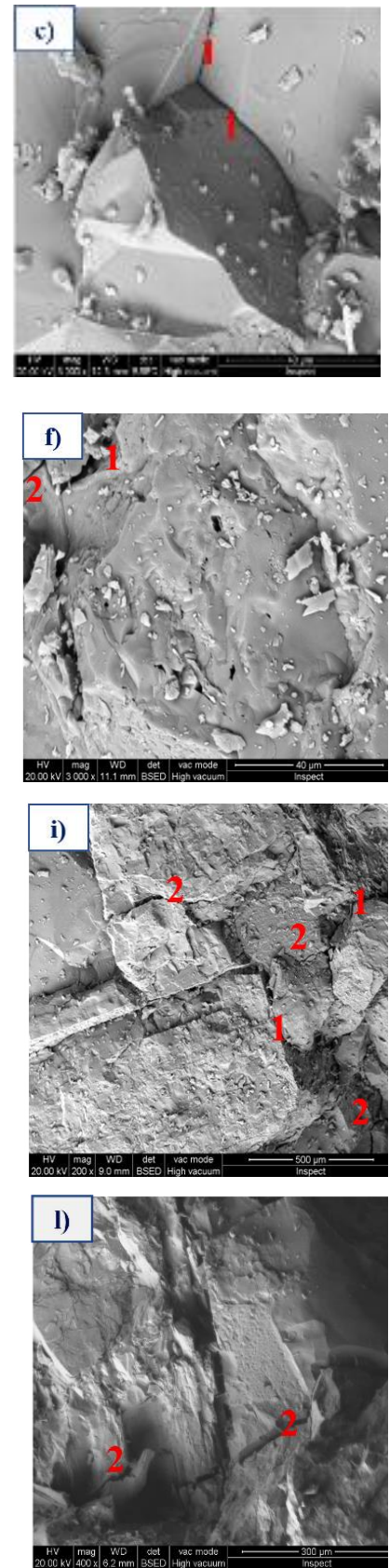

(C)

Figure 10. SEM pictures reveal microcracks generation in granodiorite samples due to thermal treatment under different cooling paths (A) oven cooling $(\mathbf{a}, \mathbf{d}, \mathbf{g}, \mathbf{j}),(\mathbf{B})$ air cooling $(\mathbf{b}, \mathbf{e}, \mathbf{h}, \mathbf{k})$, and (C) water-cooling $(\mathbf{c}, \mathbf{f}, \mathbf{i}, \mathbf{l})$. (Note: "1" for inter-granular microcracks and "2" for intra-granular microcracks). 


\subsection{Cooling Rate Impact on the Brazilian Tensile Strength}

The load-displacement curves of the Brazilian tensile test's samples demonstrating that the load linearly increased to its peak level and then dropped dramatically at failure if the heating temperature was $400{ }^{\circ} \mathrm{C}$ or less, indicating a rapid collapse of the sample and brittle failure mode (as shown in Figure 11) [78]. Moreover, the water-cooled samples had the lowest bearing capacities. The granodiorite specimens preserved their bearing capacities beyond the peak and displayed a small elastic area when the heating temperature exceeded $400{ }^{\circ} \mathrm{C}$, but the loading displacement drastically increased at $600{ }^{\circ} \mathrm{C}$. On the other hand, all samples could hardly withstand the loading force at $800{ }^{\circ} \mathrm{C}$, regardless of the cooling process, indicating that they had a low tensile strength. The tensile strength of granodiorite diminished as the heating temperature increased, as shown in Figure 12. In contrast to the oven-cooled or air-cooled samples up to $400{ }^{\circ} \mathrm{C}$, the tensile strength of watercooled samples was the weakest. The results of peak tensile strength vs. heating/cooling treatments of tested samples are included in Table 3. When samples were heated to 200, 400,600 , and $800{ }^{\circ} \mathrm{C}$ and then cooled within the oven, the tensile strengths declined by $6.06 \%, 17.16 \%, 58.34 \%$, and $85.76 \%$, respectively, of the original tensile strength.
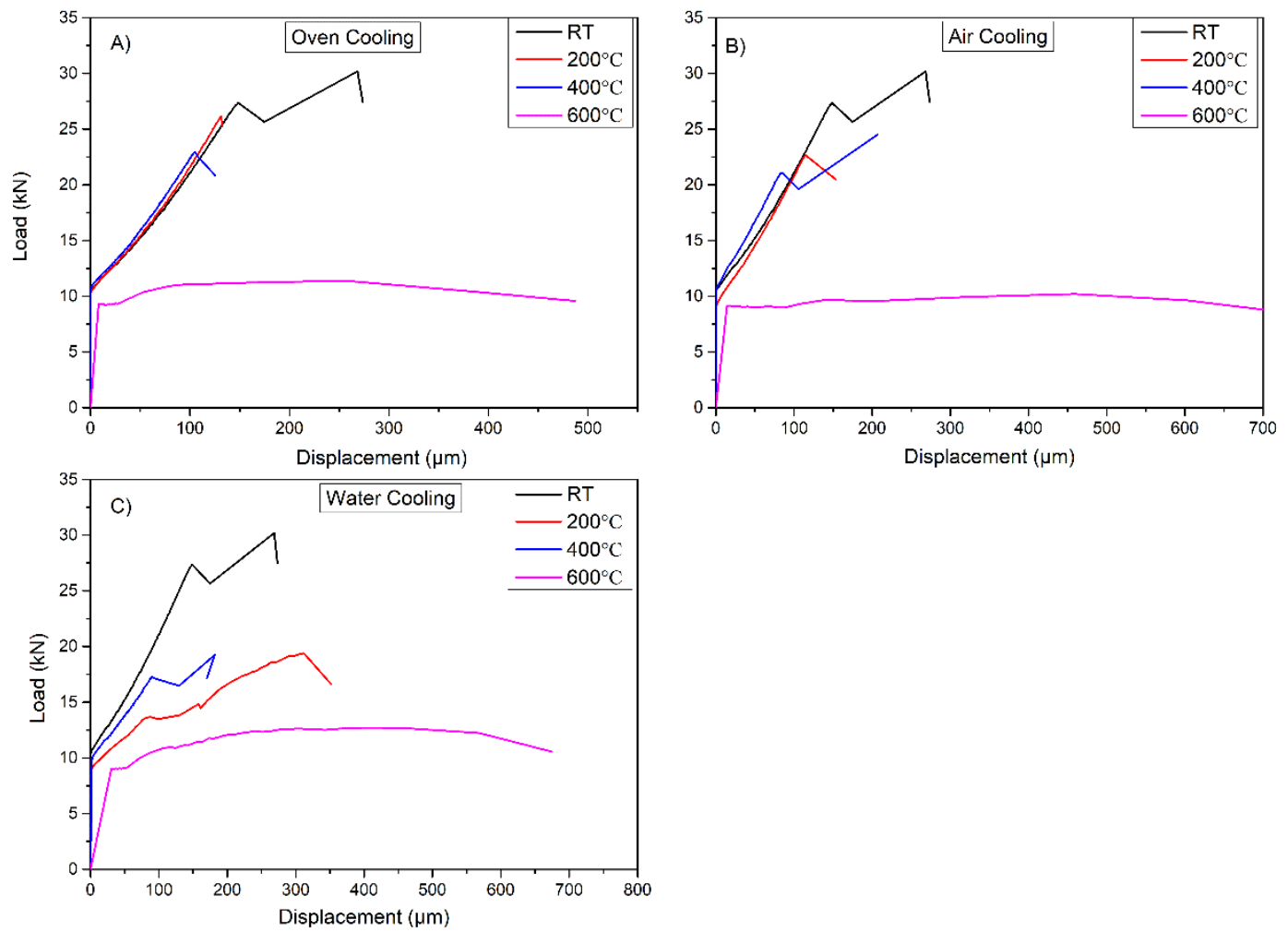

Figure 11. Granodiorite samples' loading capacity vs. displacement for various three heating/cooling methods; oven cooling (A), air cooling (B), and water cooling (C). 




Figure 12. The behavior of the tensile strength vs. the target temperature for various cooling methods.

Table 3. The granodiorite samples' tensile strength following various heating/cooling treatments, where $\sigma_{t}$ : the tensile strength; av $\sigma_{t}$ : the average tensile strength; D.F(T): the thermal damage factor for heated samples $\left(1-\sigma_{t(T)} / \sigma_{t(R T)}\right)$.

\begin{tabular}{|c|c|c|c|c|c|c|c|c|c|}
\hline \multirow[b]{2}{*}{$\begin{array}{c}\text { Temperature } \\
{ }^{\circ} \mathrm{C}\end{array}$} & \multicolumn{3}{|c|}{ Oven Cooling } & \multicolumn{3}{|c|}{ Air Cooling } & \multicolumn{3}{|c|}{ Water Cooling } \\
\hline & $\begin{array}{c}\sigma_{\mathrm{t}} \\
(\mathrm{Mpa})\end{array}$ & $\begin{array}{l}\text { av } \sigma_{t} \\
(\mathbf{M p a})\end{array}$ & $\begin{array}{c}\text { D.F (T) } \\
\%\end{array}$ & $\begin{array}{c}\sigma_{\mathrm{t}} \\
(\mathrm{Mpa})\end{array}$ & $\begin{array}{l}\text { av } \sigma_{\mathrm{t}} \\
(\mathrm{Mpa})\end{array}$ & $\begin{array}{c}\text { D.F(T) } \\
\%\end{array}$ & $\begin{array}{c}\sigma_{\mathrm{t}} \\
(\mathrm{Mpa})\end{array}$ & $\begin{array}{l}\text { av } \sigma_{\mathrm{t}} \\
(\mathrm{Mpa})\end{array}$ & $\begin{array}{c}\text { D.F(T) } \\
\%\end{array}$ \\
\hline \multirow{3}{*}{25} & 9.42 & \multirow{3}{*}{10.11} & & 9.42 & \multirow{3}{*}{10.11} & \multirow{3}{*}{-} & 9.42 & \multirow{3}{*}{10.11} & \multirow{3}{*}{-} \\
\hline & 9.84 & & - & 9.84 & & & 9.84 & & \\
\hline & 11.06 & & & 11.06 & & & 11.06 & & \\
\hline \multirow{3}{*}{200} & 9.29 & \multirow{3}{*}{9.49} & \multirow{3}{*}{6.06} & 8.19 & \multirow{3}{*}{9.65} & \multirow{3}{*}{4.54} & 7.79 & \multirow{3}{*}{8.07} & \multirow{3}{*}{20.12} \\
\hline & 9.93 & & & 10.99 & & & 8.11 & & \\
\hline & 9.27 & & & 9.77 & & & 8.32 & & \\
\hline \multirow{3}{*}{400} & 8.47 & \multirow{3}{*}{8.37} & \multirow{3}{*}{17.16} & 7.95 & \multirow{3}{*}{8.37} & \multirow{3}{*}{17.15} & 7.00 & \multirow{3}{*}{7.47} & \multirow{3}{*}{26.05} \\
\hline & 8.23 & & & 8.46 & & & 7.95 & & \\
\hline & 8.41 & & & 8.71 & & & - & & \\
\hline \multirow{3}{*}{600} & 4.34 & \multirow{3}{*}{4.21} & \multirow{3}{*}{58.34} & 3.65 & \multirow{3}{*}{3.57} & \multirow{3}{*}{64.69} & 4.32 & \multirow{3}{*}{4.08} & \multirow{3}{*}{59.63} \\
\hline & 3.65 & & & 3.47 & & & 4.48 & & \\
\hline & 4.64 & & & 3.58 & & & 3.44 & & \\
\hline \multirow{3}{*}{800} & 1.49 & \multirow{3}{*}{1.44} & \multirow{3}{*}{85.76} & 1.27 & \multirow{3}{*}{1.26} & \multirow{3}{*}{87.52} & 1.08 & & \\
\hline & 1.56 & & & 1.24 & & & 0.92 & 1.09 & 89.18 \\
\hline & 1.26 & & & 1.27 & & & 1.28 & & \\
\hline
\end{tabular}

For the samples cooled in air, the tensile strength reductions rates were $4.54 \%, 17.15 \%$, $64.69 \%$, and $87.52 \%$, respectively, and for the specimens quenched in water, the strength reductions were $20.12 \%, 26.05 \%, 59.63 \%$, and $89.18 \%$, respectively, as further revealed in Figure 13. The test analysis displayed that when the temperature was less than $400{ }^{\circ} \mathrm{C}$, the rate of tensile strength reduction for samples cooled in the oven and the air was comparable, while noticeably higher for water-cooled samples. Additionally, the SEM investigation pointed out an increase in trans-granular cracking, which supports the higher strength loss 
for the water-cooled samples. This is contradicted by [34], who noticed that cooling in air or water for granite samples had a similar effect on Brazilian tensile strength under $400{ }^{\circ} \mathrm{C}$ (as shown in Figure 14).

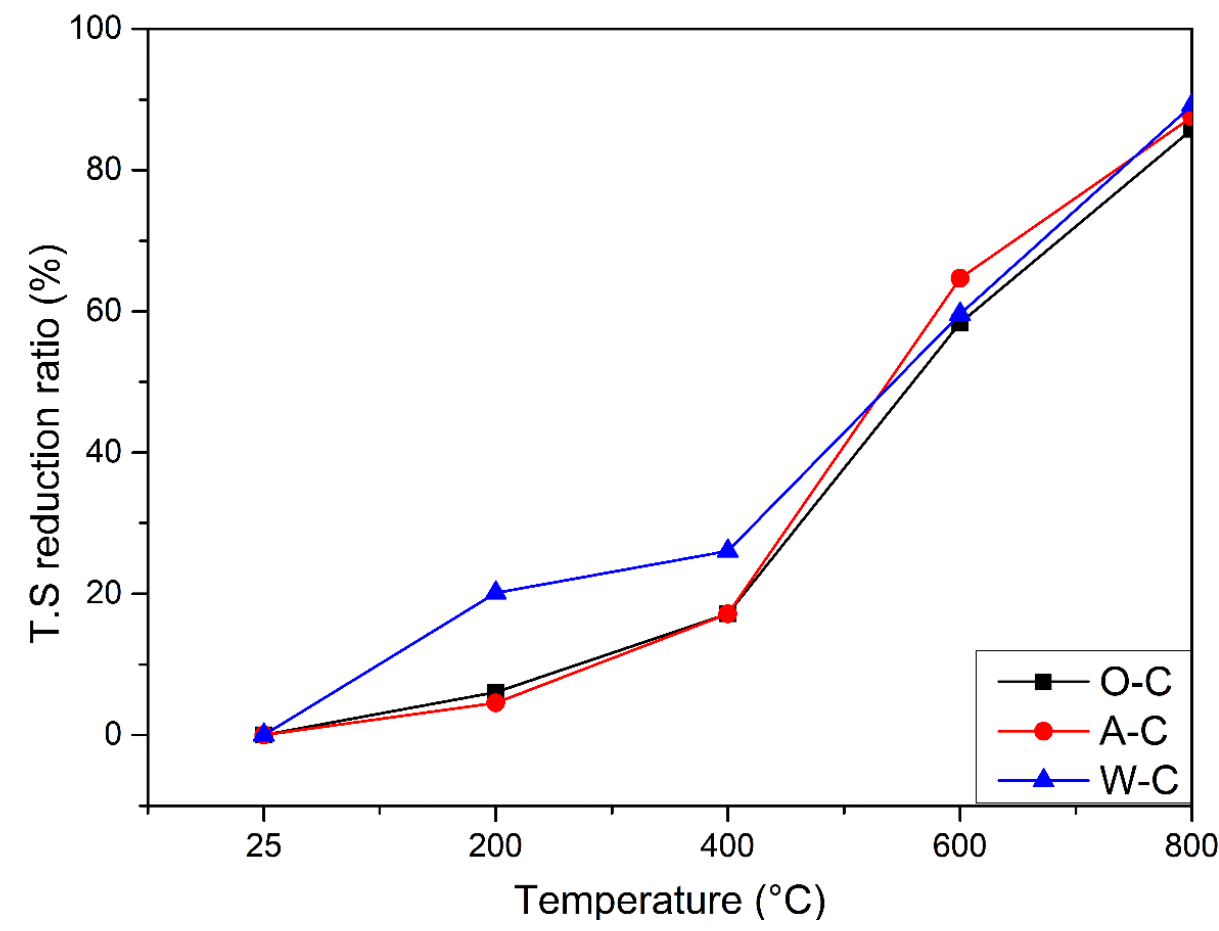

Figure 13. The tensile strength reduction ratios, due to the target temperature and several cooling methods.

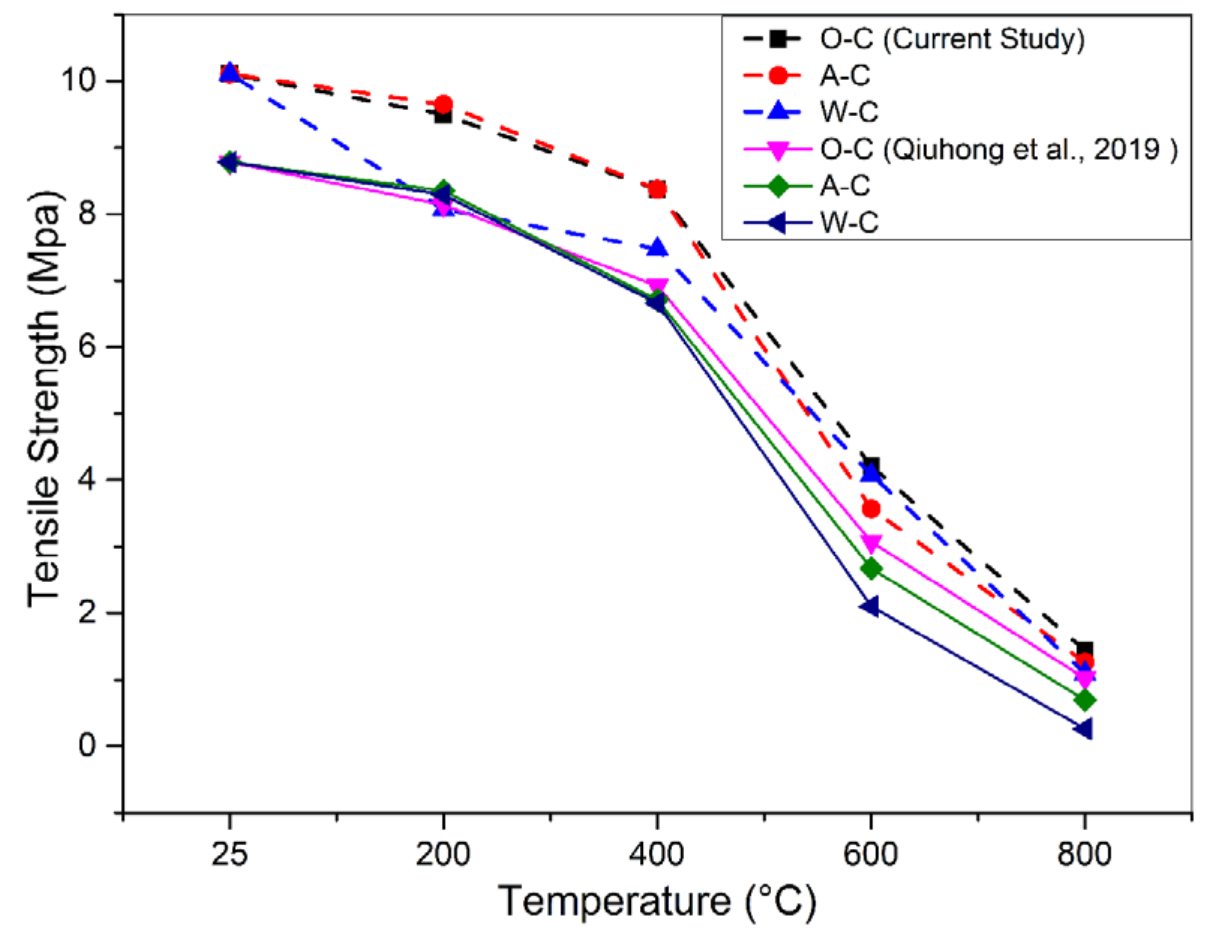

Figure 14. Tensile intensity variation as a function of target temperature, comparison the current study (dash lines) and Qiuhong et al. (2019) (solid lines). 
Once the treating temperature increased to $600{ }^{\circ} \mathrm{C}$ or higher, the tensile strengths of the granodiorite specimens were distinctly diminished. The studied granodiorite is rich in plagioclase and feldspar that generate a lower tensile strength [79]. Therefore, the disintegration of plagioclase and feldspar with increasing temperature is also a prime cause of this reduction. Another significant contributor is the thermal differential expansion of granodiorite minerals. In this period, specimens that cooled in the air were clearly the weakest, followed by those cooled in water, and lastly, inside the oven. All samples could hardly bear the loading force at $800^{\circ} \mathrm{C}$, for all the cooling process, resulting in a very low tensile strength.

\subsection{The Effect of Temperature on the Failure Modes and Color of Granodiorite}

The effect of heat treatment on the color change of Egyptian granodiorite is shown in Figure 15. Despite the cooling path, there was only a modest color shift, with the samples' colors fading slightly as the treatment heat increased. As illustrated in Figure 16, the specimens in this investigation showed three types of failure modes (single central failure (Figure 16a,b,d,e), multiple center fractures (Figure 16c,f), and failure as scattered cracking zone (Figure $16 \mathrm{~g}-1$ ). Hence, the granodiorite's failure mode during the splitting tensile test is affected by the heat treatment. The granodiorite specimen (oven and air) failed brittlely into two identical halves up to $400{ }^{\circ} \mathrm{C}$ [78], with a single crack following the loading path (Figure 16a,b,d,e). The crack initiation is more likely to happen at the edges of an inner defect, including a rock granule boundary, porous medium, micro-voids, and natural cracks [33]. Water-cooled samples were the only ones to fail, with multiple center fractures (Figure 16c,f). Furthermore, for all tested samples, no apparent surface cracks were observed at or before $400{ }^{\circ} \mathrm{C}$.
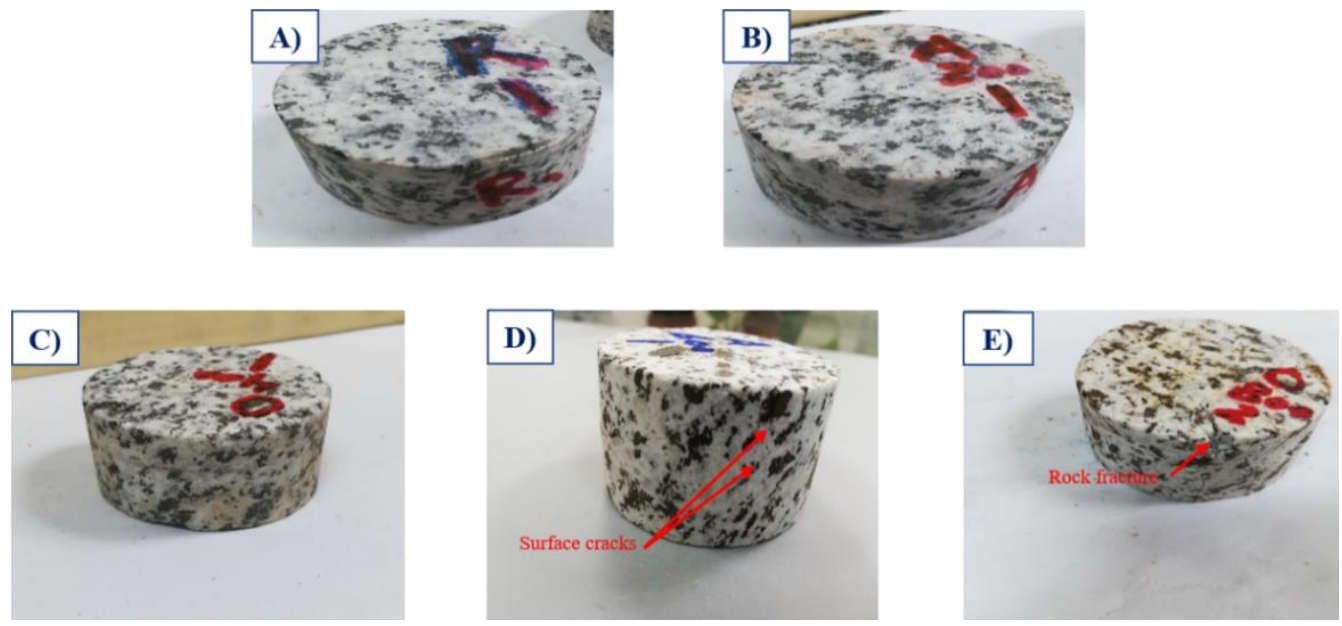

Figure 15. The change in granodiorite appearance at room temperature (A) and after the studied thermal treatments; 200 (B), $400\left(\right.$ C), 600 (D), and $800{ }^{\circ} \mathrm{C}(\mathrm{E})$.

At $600{ }^{\circ} \mathrm{C}$ and above, surface cracks have been observed on granodiorite samples, before loading, regardless of the cooling way, and the cooling rates had distinct effects on the failure modes generated by the split test (Figure $16 \mathrm{~g}-1$ ). In this phase, the failure pattern changed from central failure to multiple center fractures [19]. The rock encountered numerous complex variations, such as mineral decomposition, water escape, and the quartz phase transformation. As a result, compounded tensile cracks grow parallel to the loading orientation as the treatment temperature increases, generating a diametrically scattered cracking zone. Additionally, these results indicate that thermal treatment significantly augmented the ductility of granodiorite, agreeing with the outcomes of the load-displacement relationships. With the continuous increase in treatment temperature, the surface cracks shifted deeper, forming a much weaker structure at $800^{\circ} \mathrm{C}$. Therefore, the high temperature is the foremost motive for this change, regardless of the cooling methods used. 

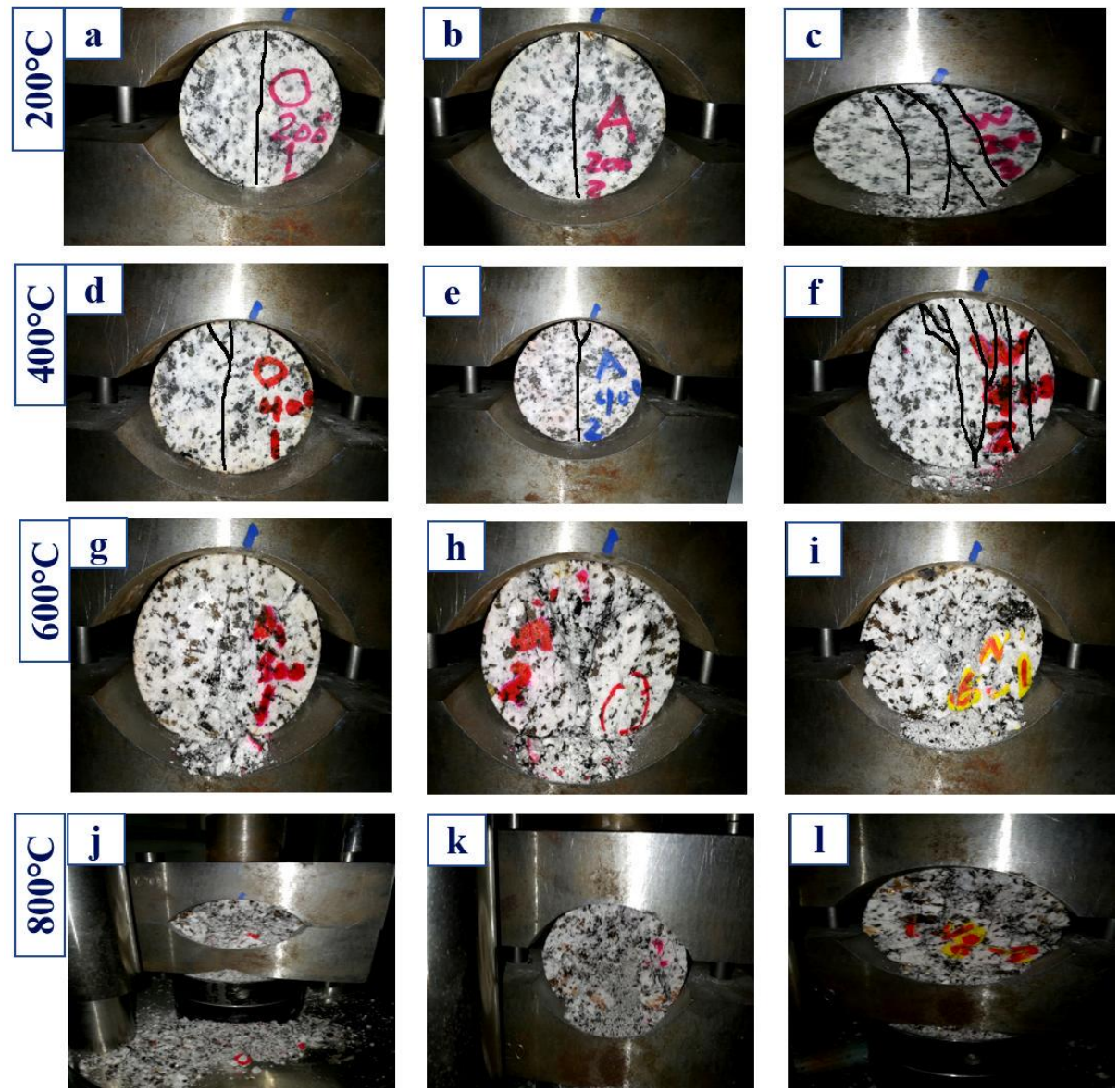

Figure 16. The evolution of granodiorite failure modes for the different cooling paths (oven, air, and water cooling) with the various temperature ranges; $200{ }^{\circ} \mathrm{C}(\mathbf{a}-\mathbf{c}), 400{ }^{\circ} \mathrm{C}(\mathbf{d}-\mathbf{f}), 600{ }^{\circ} \mathrm{C}(\mathbf{g}-\mathbf{i})$, and $800{ }^{\circ} \mathrm{C}(\mathbf{j}-\mathbf{1})$.

\section{Discussions}

It is critical to investigate the impact of high temperature on the physical and mechanical properties to control hazards in high-temperature deep geotechnical applications. Consequently, this study was based on examining the physical and mechanical features of granodiorite in association with microstructure deterioration under the effect of different heating/cooling techniques. Hence, the rock behaviors for heating and cooling pathways can be summarized into three stages based on this investigation:

Phase I: $25-400{ }^{\circ} \mathrm{C}:$ : This phase principally included the loss of water within the rock, changes in mass and volume, and the beginning and spread of cracks [33]. Therefore, the rise in porosity and absorption were small for all cooling methods. Water-cooled samples showed the highest values [34], while the oven-cooled and air-cooled samples had identical values (Figure 4). On the other hand, the P-wave velocity reduction of granodiorite was monotonically in response to a change in treatment temperature, and the water-cooled samples were the most degraded [80]. The main reason for that was that the amount of escaping locked voids (absorbed, interlayer, and mineral waters) are very small. Hence, the granodiorite had only slight chemical/structural alterations by a minor widening of pre-existing micro-cracks and/or the formation and expansion of new cracks, which was confirmed by SEM examinations, Figures 9 and 10a-f. Regarding granodiorite density, the density has consistently reduced at a slow rate due to the lower mass loss and the slight increase in volume in this phase [31]. The three cooling methods recorded comparable amounts for density (Figure 5), which meant that the granodiorite density was not affected by the cooling methods under the lower temperatures. Additionally, water-cooled samples had the lowest tensile strength [19] with multiple center fractures when compared to oven 
or air-cooled samples that failed brittlely into two halves (Figure 16a-f). This is contradicted by [34], who noticed that cooling in air or water for granite samples had a similar effect on Brazilian tensile strength under $400{ }^{\circ} \mathrm{C}$, as shown in Figure 14 . These results promote the granodiorite for geothermal applications such as enhanced geothermal systems (EGS) and nuclear waste disposal sites, but under slow cooling conditions.

Phase II: $400-600{ }^{\circ} \mathrm{C}$ : It is considered a transitional phase where physical and mechanical properties of noticeable degradation have been initiated. The temperature increase had an accelerating impact on physical and mechanical parameters. The physical characteristics of various granodiorite minerals changed in Phase II [61,81,82]. The $\alpha$-quartz phase, for example, was transformed into the $\beta$-quartz phase at $573{ }^{\circ} \mathrm{C}$ [83], leading to substantial changes in porosity, absorption, and density. Additionally, the $\alpha-\beta$ transition was also accountable for the change in the sample's color (Figure 15d). The principal explanations are that quartz has four times the volume expansion when compared to feldspar [84]. Therefore, rocks composed principally of quartz and feldspar undergo dramatic structural changes as temperatures rise, and microcracks commonly formed granodiorite samples because of these differences in volume expansions [85,86]. Additionally, new cracks can appear once the overall thermal stress passes the mineral/interface tensile or shear strength thresholds, and the original cracks propagate potentially, causing structural destruction to rocks [50]. Hence, the consumption threshold of longitudinal wave velocity started after the $400{ }^{\circ} \mathrm{C}$ limits, and the compressional wave velocity distinctly decreased for all cooling paths. Additionally, the post-peak stage of the load-displacement curve significantly expanded, and the tensile strengths of the granodiorite specimens were sharply diminished, demonstrating that granodiorite behavior altered from a brittle to a ductile failure after $400{ }^{\circ} \mathrm{C}$, as concurred with $[19,64,87]$. Meanwhile, the linear elastic displacement in samples could not be determined when microcracks occurred in specimens before the test [88]. This is consistent with the results of this study for specimens at $600{ }^{\circ} \mathrm{C}$. Therefore, the linear elastic area dramatically diminished in samples heated above $400{ }^{\circ} \mathrm{C}$, attributed to the fact that the studied granodiorite is rich in plagioclase and feldspar, which generate a lower tensile strength [79]. Therefore, the disintegration of plagioclase and feldspar with increasing temperature was also a prime cause of this reduction. Consequently, the engineering application at that temperature must consider the general weakening impact of heat on the carrying capacity of the rock in this stage.

Phase III: 600:800 ${ }^{\circ} \mathrm{C}$ : The granodiorite sustained considerable damage and lost its integrity to carry loads at all cooling paths, resulting in significant fluctuations in porosity, absorption, and density. Additionally, due to the fusion of thermal trans granular cracks (Figure 15e), longitudinal waves failed to penetrate the rock specimens, and measuring the longitudinal wave velocity at $800{ }^{\circ} \mathrm{C}$ was impossible [46]. In this phase, the difference in thermal expansion between minerals approaches a maximum, and some minerals begin to melt and decompose, resulting in more flaws and a large increase in porosity [18]. Regardless of the cooling technique, sample integrity had been compromised for the $800{ }^{\circ} \mathrm{C}$ specimens, and numerous thermal microcracks had been stimulated to link and coalescence (Figure 10j-1), resulting in significantly higher macroscopic crack density and fissure widths than at $\mathrm{T}=600^{\circ} \mathrm{C}$. Hence, all samples could hardly bear the loading force at $800^{\circ} \mathrm{C}$, for all the cooling processes, resulting in a very low tensile strength. Therefore, this temperature level is pointing to possible thermal cutting practices of granodiorite for dimensional stone mining.

\section{Conclusions}

Temperature is a critical element in the design of many geological engineering applications (geothermal energy exploitation, fire exposed ornamental stones, nuclear waste disposal, $\mathrm{CO}_{2}$ storage, etc.). The granodiorite rock is predominant in Egyptian geology and is a possible target for thermal UG designs. Accordingly, the physical and mechanical properties of granodiorite rock were investigated after stepped heat treatment up to $800{ }^{\circ} \mathrm{C}$. The heating stage is followed by a slow cooling path (oven and air) and rapid cooling by 
water. The XRD and SEM have assessed temperature's effects on the granodiorite physical and chemical changes. The rock tensile strength was then tested by the indirect Brazilian tests to follow the evolution of tensile strength degradation. The study concluded the following:

(1) The physical properties of granodiorite change substantially when exposed to thermal treatment. The characteristics vary moderately up to a particular temperature $\left(400{ }^{\circ} \mathrm{C}\right)$ but do not differ much between cooling paths. At this stage, P-wave velocity, mass, and density show a decreasing trend, while porosity and absorption show an increasing trend. After this temperature, the change of these physical parameters is striking and irreversible.

(2) The difference in the sample's tensile strength was closely linked to the target temperature and cooling path. When the temperature was less than $400^{\circ} \mathrm{C}$, the reduction rate and failure mode in the specimens cooled in the oven and air were nearly identical (in contrast with water-cooled samples that were different in value and mode of failure). Nevertheless, when the temperature increased to $600^{\circ} \mathrm{C}$, the failure pattern developed from individual central to multiple center fractures for all cooling methods. At $800{ }^{\circ} \mathrm{C}$, surface cracks were prompted to go deeper inward, and all samples were unable to withstand the loading, regardless of the cooling process, resulting in a very low tensile strength.

(3) SEM analysis reveals microstructure damage because of heat/cooling treatment. At temperatures as high as $200^{\circ} \mathrm{C}$, no substantial thermally induced microcracks have appeared, except for the water-cooling route. When the temperature approached $400{ }^{\circ} \mathrm{C}$, the thermal expansions of the various minerals caused thermal stresses inside the granodiorite framework in the form of an inter-granular crack (oven-cooled and air-cooled) or inter-granular and trans-granular cracks (water-cooled). Granodiorite has been damaged at $600^{\circ} \mathrm{C}$ and above; the small cracks inside the samples have been extended regardless of the cooling path.

(4) The study showed that the $400{ }^{\circ} \mathrm{C}$ is a critical threshold temperature for granodiorite thermal damage. Hence, the Egyptian granodiorite may host geothermal underground applications up to $400{ }^{\circ} \mathrm{C}$ with normal physical and mechanical responses under slow cooling paths, but with the potential degradation of rock behavior under rapid water cooling.

The research assists in the evaluation of rock responses to temperature in future Egyptian deep geotechnical applications, such as nuclear waste disposal, mining of dimensional stone, geothermal resource management, and underground coal gasification.

\section{Recommendation}

Future research may incorporate the use of the sensitivity analysis technique to demonstrate how variations or uncertainties in variable inputs like porosity, p-wave velocity, and so on can affect expected output (thermal damage) after heating/cooling processes. This technique can be applied to the high-complexity modelling process and then overcome.

Author Contributions: conceptualization, M.E.G.; methodology, M.E.G., validation, M.E.G., S.B., and G.L.; analysis, M.E.G.; writing—original draft, M.E.G.; writing—review and editing, M.E.G., S.B., G.L., M.E., and M.I.; supervision, M.E.G. and G.L.; funding acquisition, G.L.; lab tests, M.E.G., M.E., and M.I. All authors have read and agreed to the published version of the manuscript.

Funding: This research was funded by Fundamental Research Funds for the Central Universities (2020ZDPY0221), Project "51574224", supported by National Natural Science Foundation of China.

Acknowledgments: I would like to express my gratitude to Khaled Abdelghafar for his assistance in carrying out the experiments as a member of the Rock Engineering Laboratory (REL), Faculty of Engineering, Cairo University (FECU).

Conflicts of Interest: The authors declare no conflict of interest. 


\section{References}

1. Olasolo, P.; Juárez, M.C.; Morales, M.P.; Liarte, I.A. Enhanced geothermal systems (EGS): A review. Renew. Sustain. Energy Rev. 2016, 56, 133-144. [CrossRef]

2. McClure, M.W.; Horne, R.N. An investigation of stimulation mechanisms in Enhanced Geothermal Systems. Int. J. Rock Mech. Min. Sci. 2014, 72, 242-260. [CrossRef]

3. Kolditz, O.; Clauser, C. Numerical simulation of flow and heat transfer in fractured crystalline rocks: Application to the hot dry rock site in Rosemanowes (UK). Geothermics 1998, 27, 1-23. [CrossRef]

4. Wan, Z.; Zhao, Y.; Kang, J. Forecast and evaluation of hot dry rock geothermal resource in China. Renew. Energy 2005, 30, 1831-1846. [CrossRef]

5. Feng, Z.; Zhao, Y.; Zhou, A.; Zhang, N. Development program of hot dry rock geothermal resource in the Yangbajing Basin of China. Renew. Energy 2012, 39, 490-495. [CrossRef]

6. Zhao, Y.; Feng, Z.; Xi, B.; Wan, Z.; Yang, D.; Liang, W. Deformation and instability failure of borehole at high temperature and high pressure in Hot Dry Rock exploitation. Renew. Energy 2015, 77, 159-165. [CrossRef]

7. Kumari, W.G.P.; Ranjith, P.G.; Perera, M.S.A.; Chen, B.K. Experimental investigation of quenching effect on mechanical, microstructural and flow characteristics of reservoir rocks: Thermal stimulation method for geothermal energy extraction. J. Pet. Sci. Eng. 2018, 162, 419-433. [CrossRef]

8. Breede, K.; Dzebisashvili, K.; Liu, X.; Falcone, G. A systematic review of enhanced (or engineered) geothermal systems: Past, present and future. Geotherm. Energy 2013, 1, 4. [CrossRef]

9. Barla, G. Comprehensive study including testing, monitoring and thermo-hydro modelling for design and implementation of a geothermal system in Torino (Italy). Geomech. Geophys. Geo Energy Geo Resour. 2017, 3, 175-188. [CrossRef]

10. Laughlin, A.W.; Eddy, A.C.; Laney, R.; Aldrich, M.J., Jr. Geology of the Fenton Hill, New Mexico, hot dry rock site. J. Volcanol. Geotherm. Res. 1983, 15, 21-41. [CrossRef]

11. Petersson, J.; Eliasson, T. Mineral evolution and element mobility during episyenitization (dequartzification) and albitization in the postkinematic Bohus granite, southwest Sweden. Lithos 1997, 42, 123-146. [CrossRef]

12. Chen, D.; Wyborn, D. Habanero field tests in the Cooper Basin, Australia: A proof-of-concept for EGS. Geotherm. Resour. Counc. Trans. 2009, 33, 159-164.

13. Alt-Epping, P.; Diamond, L.W.; Häring, M.O.; Ladner, F.; Meier, D.B. Prediction of water-rock interaction and porosity evolution in a granitoid-hosted enhanced geothermal system, using constraints from the $5 \mathrm{~km}$ Basel-1 well. Appl. Geochem. 2013, 38, 121-133. [CrossRef]

14. O'Sullivan, M.J.; Pruess, K.; Lippmann, M.J. State of the art of geothermal reservoir simulation. Geothermics 2001, 30, 395-429. [CrossRef]

15. Tran, N.H.; Rahman, S.S. Development of hot dry rocks by hydraulic stimulation: Natural fracture network simulation. Theor. Appl. Fract. Mech. 2007, 47,77-85. [CrossRef]

16. Zeng, Y.-C.; Su, Z.; Wu, N.-Y. Numerical simulation of heat production potential from hot dry rock by water circulating through two horizontal wells at Desert Peak geothermal field. Energy 2013, 56, 92-107. [CrossRef]

17. Armstead, H.C.H. The future of geothermal energy. In Proceeding of DOE Geothermal Program Workshop, Washington, DC, USA, 7 June 2007; pp. 109-118.

18. Chandrasekharam, D.; Pabasara Kumari, W.G.; Avanthi Isaka, B.L.; Gamage, R.P.; Rathnaweera, T.D.; Anne Perera, M.S. An influence of thermally-induced micro-cracking under cooling treatments: Mechanical characteristics of Australian granite. Energies 2018, 11, 1338. [CrossRef]

19. Kumari, W.G.P.; Beaumont, D.M.; Ranjith, P.G.; Perera, M.S.A.; Avanthi Isaka, B.L.; Khandelwal, M. An experimental study on tensile characteristics of granite rocks exposed to different high-temperature treatments. Geomech. Geophys. Geo Energy Geo Resour. 2019, 5, 47-64. [CrossRef]

20. Lavis, S.; Courtney, R.; Mostade, S. Underground coal gasification. In The Coal Handbook: Towards Cleaner Production; Elsevier: Amsterdam, The Netherlands, 2013; pp. 226-239.

21. Burton, E.A.; Upadhye, R.; Friedmann, S.J. Best Practices in Underground Coal Gasification; Lawrence Livermore National Lab.(LLNL): Livermore, CA, USA, 2017.

22. Gens, A.; Guimaraes, L. do N.; Garcia-Molina, A.; Alonso, E.E. Factors controlling rock-clay buffer interaction in a radioactive waste repository. Eng. Geol. 2002, 64, 297-308. [CrossRef]

23. Rutqvist, J. The geomechanics of $\mathrm{CO}_{2}$ storage in deep sedimentary formations. Geotech. Geol. Eng. 2012, 30, 525-551. [CrossRef]

24. Griffiths, L.; Lengliné, O.; Heap, M.J.; Baud, P.; Schmittbuhl, J. Thermal cracking in Westerly Granite monitored using direct wave velocity, coda wave interferometry, and acoustic emissions. J. Geophys. Res. Solid Earth 2018, 123, 2246-2261. [CrossRef]

25. David, C.; Menéndez, B.; Darot, M. Influence of stress-induced and thermal cracking on physical properties and microstructure of La Peyratte granite. Int. J. Rock Mech. Min. Sci. 1999, 36, 433-448. [CrossRef]

26. Takarli, M.; Prince, W.; Siddique, R. Damage in granite under heating/cooling cycles and water freeze-thaw condition. Int. J. Rock Mech. Min. Sci. 2008, 45, 1164-1175. [CrossRef]

27. Nasseri, M.H.B.; Schubnel, A.; Young, R.P. Coupled evolutions of fracture toughness and elastic wave velocities at high crack density in thermally treated Westerly granite. Int. J. Rock Mech. Min. Sci. 2007, 44, 601-616. [CrossRef] 
28. Xu, X.; Kang, Z.; Ji, M.; Ge, W.; Chen, J. Research of microcosmic mechanism of brittle-plastic transition for granite under high temperature. Procedia Earth Planet. Sci. 2009, 1, 432-437.

29. Peng, J.; Rong, G.; Cai, M.; Yao, M.-D.; Zhou, C.-B. Physical and mechanical behaviors of a thermal-damaged coarse marble under uniaxial compression. Eng. Geol. 2016, 200, 88-93. [CrossRef]

30. Meng, Q.-B.; Qian, W.; Liu, J.-F.; Zhang, M.-W.; Lu, M.-M.; Wu, Y. Analysis of triaxial compression deformation and strength characteristics of limestone after high temperature. Arab. J. Geosci. 2020, 13. [CrossRef]

31. Yang, S.Q.; Xu, P.; Li, Y.B.; Huang, Y.H. Experimental investigation on triaxial mechanical and permeability behavior of sandstone after exposure to different high temperature treatments. Geothermics 2017, 69, 93-109. [CrossRef]

32. Zhang, W.; Sun, Q.; Zhu, Y.; Guo, W. Experimental study on response characteristics of micro-macroscopic performance of red sandstone after high-temperature treatment. J. Therm. Anal. Calorim. 2019, 136, 1935-1945. [CrossRef]

33. Zhang, W.; Sun, Q.; Hao, S.; Geng, J.; Lv, C. Experimental study on the variation of physical and mechanical properties of rock after high temperature treatment. Appl. Therm. Eng. 2016, 98, 1297-1304. [CrossRef]

34. Wu, Q.; Weng, L.; Zhao, Y.; Guo, B.; Luo, T. On the tensile mechanical characteristics of fine-grained granite after heating/cooling treatments with different cooling rates. Eng. Geol. 2019, 253, 94-110. [CrossRef]

35. Zhu, S.; Zhang, W.; Sun, Q.; Deng, S.; Geng, J.; Li, C. Thermally induced variation of primary wave velocity in granite from Yantai: Experimental and modeling results. Int. J. Therm. Sci. 2017, 114, 320-326. [CrossRef]

36. Zhang, R.R.; Jing, L.W.; Ma, Q.Y. Experimental Study on Thermal Damage and Energy Evolution of Sandstone after High Temperature Treatment. Shock Vib. 2018, 2018. [CrossRef]

37. Shahri, A.A.; Larsson, S.; Johansson, F. Updated relations for the uniaxial compressive strength of marlstones based on P-wave velocity and point load index test. Innov. Infrastruct. Solut. 2016, 1, 17. [CrossRef]

38. Dragon, A.; Mroz, Z. A continuum model for plastic-brittle behaviour of rock and concrete. Int. J. Eng. Sci. 1979, 17, 121-137. [CrossRef]

39. Mao, X.-B.; Zhang, L.-Y.; Li, T.-Z.; Liu, H.-S. Properties of failure mode and thermal damage for limestone at high temperature. Min. Sci. Technol. 2009, 19, 290-294. [CrossRef]

40. Heard, H.C. Thermal expansion and inferred permeability of climax quartz monzonite to $300 \mathrm{C}$ and 27.6 MPa. Int. J. Rock Mech Min. Sci. Geomech. Abstr. 1980, 17, 289-296. [CrossRef]

41. Liu, X.; Yuan, S.; Sieffert, Y.; Fityus, S.; Buzzi, O. Changes in Mineralogy, Microstructure, Compressive Strength and Intrinsic Permeability of Two Sedimentary Rocks Subjected to High-Temperature Heating. Rock Mech. Rock Eng. 2016, 49, 2985-2998. [CrossRef]

42. Reuschlé, T.; Haore, S.G.; Darot, M. Microstructural control on the elastic properties of thermally cracked granite. Tectonophysics 2003, 370, 95-104. [CrossRef]

43. Zhang, Y.; Sun, Q.; He, H.; Cao, L.; Zhang, W.; Wang, B. Pore characteristics and mechanical properties of sandstone under the influence of temperature. Appl. Therm. Eng. 2017, 113, 537-543. [CrossRef]

44. Fan, L.F.; Gao, J.W.; Wu, Z.J.; Yang, S.Q.; Ma, G.W. An investigation of thermal effects on micro-properties of granite by X-ray CT technique. Appl. Therm. Eng. 2018, 140, 505-519. [CrossRef]

45. Chaki, S.; Takarli, M.; Agbodjan, W.P. Influence of thermal damage on physical properties of a granite rock: Porosity, permeability and ultrasonic wave evolutions. Constr. Build. Mater. 2008, 22, 1456-1461. [CrossRef]

46. Wu, X.; Huang, Z.; Zhang, S.; Cheng, Z.; Li, R.; Song, H.; Wen, H.; Huang, P. Damage analysis of high-temperature rocks subjected to LN2 thermal shock. Rock Mech. Rock Eng. 2019, 52, 2585-2603. [CrossRef]

47. Browning, J.; Meredith, P.; Gudmundsson, A. Cooling-dominated cracking in thermally stressed volcanic rocks. Geophys. Res. Lett. 2016, 43, 8417-8425. [CrossRef]

48. Hale, P.A.; Shakoor, A. A laboratory investigation of the effects of cyclic heating and cooling, wetting and drying, and freezing and thawing on the compressive strength of selected sandstones. Environ. Eng. Geosci. 2003, 9, 117-130. [CrossRef]

49. Yang, S.-Q.; Tian, W.-L.; Ranjith, P.G. Failure mechanical behavior of Australian strathbogie granite at high temperatures: Insights from particle flow modeling. Energies 2017, 10, 756. [CrossRef]

50. Yang, S.-Q.; Ranjith, P.G.; Jing, H.-W.; Tian, W.-L.; Ju, Y. An experimental investigation on thermal damage and failure mechanical behavior of granite after exposure to different high temperature treatments. Geothermics 2017, 65, 180-197. [CrossRef]

51. Yavuz, H. Effect of freeze-thaw and thermal shock weathering on the physical and mechanical properties of an andesite stone. Bull. Eng. Geol. Environ. 2011, 70, 187-192. [CrossRef]

52. Zhao, Y.; Wang, Y.; Wang, W.; Wan, W.; Tang, J. Modeling of non-linear rheological behavior of hard rock using triaxial rheological experiment. Int. J. Rock Mech. Min. Sci. 2017, 93, 66-75. [CrossRef]

53. Brotons, V.; Tomás, R.; Ivorra, S.; Alarcón, J.C. Temperature influence on the physical and mechanical properties of a porous rock: San Julian's calcarenite. Eng. Geol. 2013, 167, 117-127. [CrossRef]

54. Hao, S.; Wasantha, P.L.P.; Ranjith, P.G.; Chen, B.K. Effect of cooling rate on the mechanical behavior of heated Strathbogie granite with different grain sizes. Int. J. Rock Mech. Min. Sci. 2014, 70, 381-387.

55. Rathnaweera, T.D.; Ranjith, P.G.; Gu, X.; Perera, M.S.A.; Kumari, W.G.P.; Wanniarachchi, W.A.M.; Haque, A.; Li, J.C. Experimental investigation of thermomechanical behaviour of clay-rich sandstone at extreme temperatures followed by cooling treatments. Int. J. Rock Mech. Min. Sci. 2018, 107, 208-223. [CrossRef] 
56. Zhang, F.; Zhao, J.; Hu, D.; Skoczylas, F.; Shao, J. Laboratory Investigation on Physical and Mechanical Properties of Granite After Heating and Water-Cooling Treatment. Rock Mech. Rock Eng. 2018, 51, 677-694. [CrossRef]

57. Zhao, Z.; Liu, Z.; Pu, H.; Li, X. Effect of Thermal Treatment on Brazilian Tensile Strength of Granites with Different Grain Size Distributions. Rock Mech. Rock Eng. 2018, 51, 1293-1303. [CrossRef]

58. Yin, T.; Li, X.; Cao, W.; Xia, K. Effects of thermal treatment on tensile strength of Laurentian granite using Brazilian test. Rock Mech. Rock Eng. 2015, 48, 2213-2223. [CrossRef]

59. Wang, Z.L.; Shi, G.Y. Effect of heat treatment on dynamic tensile strength and damage behavior of medium-fine-grained huashan granite. Exp. Tech. 2017, 41,365-375. [CrossRef]

60. Yao, W.; Xu, Y.; Wang, W.; Kanopolous, P. Dependence of dynamic tensile strength of longyou sandstone on heat-treatment temperature and loading rate. Rock Mech. Rock Eng. 2016, 49, 3899-3915. [CrossRef]

61. Dwivedi, R.D.; Goel, R.K.; Prasad, V.V.R.; Sinha, A. Thermo-mechanical properties of Indian and other granites. Int. J. Rock Mech. Min. Sci. 2008, 45, 303-315. [CrossRef]

62. Roy, D.G.; Singh, T.N.; Kodikara, J.; Das, R. Effect of water saturation on the fracture and mechanical properties of sedimentary rocks. Rock Mech. Rock Eng. 2017, 50, 2585-2600.

63. Cai, M.; Kaiser, P.K.; Tasaka, Y.; Maejima, T.; Morioka, H.; Minami, M. Generalized crack initiation and crack damage stress thresholds of brittle rock masses near underground excavations. Int. J. Rock Mech. Min. Sci. 2004, 41, 833-847. [CrossRef]

64. Shao, S.; Ranjith, P.G.; Wasantha, P.L.P.; Chen, B.K. Experimental and numerical studies on the mechanical behaviour of Australian Strathbogie granite at high temperatures: An application to geothermal energy. Geothermics 2015, 54, 96-108. [CrossRef]

65. El-Taher, A.; Uosif, M.A.M.; Orabi, A.A. Natural radioactivity levels and radiation hazard indices in granite from Aswan to Wadi El-Allaqi southeastern desert, Egypt. Radiat. Prot. Dosim. 2007, 124, 148-154. [CrossRef] [PubMed]

66. Standard Test Method for Compressive Strength and Elastic Moduli of Intact Rock Core Specimens under Varying States of Stress and Temperatures; ASTM International: West Conshohocken, PA, USA, 2010.

67. Somerton, W.H. Thermal Properties and Temperature-Related Behavior of Rock/Fluid Systems; Elsevier: Amsterdam, The Netherlands, 1992; ISBN 0444890017. [CrossRef]

68. Hajpál, M.; Török, Á. Mineralogical and colour changes of quartz sandstones by heat. Environ. Geol. 2004, 46, 311-322. [CrossRef]

69. Sumner, P.D.; Loubser, M.J. Experimental sandstone weathering using different wetting and drying moisture amplitudes. Earth Surf. Process. Landf. J. Br. Geomorphol. Res. Gr. 2008, 33, 985-990. [CrossRef]

70. Tian, H.; Kempka, T.; Xu, N.-X.; Ziegler, M. Physical properties of sandstones after high temperature treatment. Rock Mech. rock Eng. 2012, 45, 1113-1117. [CrossRef]

71. Gautam, P.K.; Verma, A.K.; Jha, M.K.; Sharma, P.; Singh, T.N. Effect of high temperature on physical and mechanical properties of Jalore granite. J. Appl. Geophys. 2018, 159, 460-474. [CrossRef]

72. Franklin, J.A. Suggest methods for determining water content, porosity, density, absorption and related properties and swelling and slake-durability index properties. Int. J. Rock Mech. Min. Sci. Geomech. Abstr. 1979, 16, 141-156.

73. Peng, J.; Yang, S.-Q. Comparison of mechanical behavior and acoustic emission characteristics of three thermally-damaged rocks. Energies 2018, 11, 2350. [CrossRef]

74. Wang, P.; Yin, T.; Li, X.; Zhang, S.; Bai, L. Dynamic properties of thermally treated granite subjected to cyclic impact loading. Rock Mech. Rock Eng. 2019, 52, 991-1010. [CrossRef]

75. Li, D.; Wong, L.N.Y. The Brazilian disc test for rock mechanics applications: Review and new insights. Rock Mech. rock Eng. 2013, 46, 269-287. [CrossRef]

76. Kim, K.M.; Kemeny, J. Effect of thermal shock and rapid unloading on mechanical rock properties. In Proceedings of the 43rd US Rock Mechanics Symposium \& 4th US-Canada Rock Mechanics Symposium, Asheville, NC, USA, 28 June-1 July 2009; American Rock Mechanics Association: Alexandria, VA, USA, 2009.

77. Zhang, J.; Shen, Y.; Yang, G.; Zhang, H.; Wang, Y.; Hou, X.; Sun, Q.; Li, G. Inconsistency of changes in uniaxial compressive strength and P-wave velocity of sandstone after temperature treatments. J. Rock Mech. Geotech. Eng. 2021, 13, 143-153. [CrossRef]

78. Wang, F.; Konietzky, H.; Frühwirt, T.; Li, Y.; Dai, Y. The influence of temperature and high-speed heating on tensile strength of granite and the application of digital image correlation on tensile failure processes. Rock Mech. Rock Eng. 2020, 53, 1935-1952. [CrossRef]

79. Fujii, Y.; Takemura, T.; Takahashi, M.; Lin, W. Surface features of uniaxial tensile fractures and their relation to rock anisotropy in Inada granite. Int. J. Rock Mech. Min. Sci. 2007, 44, 98-107. [CrossRef]

80. Géraud, Y. Variations of connected porosity and inferred permeability in a thermally cracked granite. Geophys. Res. Lett. 1994, 21, 979-982. [CrossRef]

81. Ranjith, P.G.; Viete, D.R.; Chen, B.J.; Perera, M.S.A. Transformation plasticity and the effect of temperature on the mechanical behaviour of Hawkesbury sandstone at atmospheric pressure. Eng. Geol. 2012, 151, 120-127.

82. Vagnon, F.; Colombero, C.; Colombo, F.; Comina, C.; Ferrero, A.M.; Mandrone, G.; Vinciguerra, S.C. Effects of thermal treatment on physical and mechanical properties of Valdieri Marble-NW Italy. Int. J. Rock Mech. Min. Sci. 2019, 116, 75-86. [CrossRef]

83. Ohno, I. Temperature variation of elastic properties of $\alpha$-quartz up to the $\alpha$ - $\beta$ transition. J. Phys. Earth 1995, 43, 157-169. [CrossRef]

84. Sirdesai, N.N.; Mahanta, B.; Ranjith, P.G.; Singh, T.N. Effects of thermal treatment on physico-morphological properties of Indian fine-grained sandstone. Bull. Eng. Geol. Environ. 2019, 78, 883-897. [CrossRef] 
85. Siegesmund, S.; Ullemeyer, K.; Weiss, T.; Tschegg, E.K. Physical weathering of marbles caused by anisotropic thermal expansion. Int. J. Earth Sci. 2000, 89, 170-182. [CrossRef]

86. Tian, H.; Ziegler, M.; Kempka, T. Physical and mechanical behavior of claystone exposed to temperatures up to $1000{ }^{\circ} \mathrm{C}$. Int. J. Rock Mech. Min. Sci. 2014, 70, 144-153. [CrossRef]

87. Hueckel, T.; Peano, A.; Pellegrini, R. A thermo-plastic constitutive law for brittle-plastic behavior of rocks at high temperatures. Pure Appl. Geophys. 1994, 143, 483-510. [CrossRef]

88. Perras, M.A.; Diederichs, M.S. A review of the tensile strength of rock: Concepts and testing. Geotech. Geol. Eng. 2014, 32, 525-546. [CrossRef] 